\title{
RACE AS IDENTITY CARICATURE: A LOCAL LEGAL HISTORY LESSON IN THE SALIENCE OF INTRARACIAL CONFLICT
}

\author{
TOMIKO BROWN-NAGIN ${ }^{\dagger}$
}

\section{INTRODUCTION}

In a seminal article published in The Yale Law Joumal during the late 1970s, Professor Derrick Bell offered a stinging critique of the country's premier public interest law firm.' Bell critiqued conflicts that developed between attorneys for the NAACP Legal Defense Fund (LDF) and clients whom they represented in the Detroit, ${ }^{2}$ Atlanta, ${ }^{3}$ and Boston ${ }^{4}$ school desegregation class actions. He concluded that in all three cases the lawyer-client conflict stemmed from a common source: LDF's failure to reconsider its policy of pursuing racialbalance orders as the sole remedy for de jure segregation of public schools after it became apparent that such orders no longer were politically or legally viable. LDF attorneys were remiss, Bell claimed, in rigidly adhering to the notion that Brown $v$. Board of Education ${ }^{5}$ re-

\footnotetext{
${ }^{\dagger}$ Associate Professor of Law and History, Washington University (St. Louis). I thank the following individuals for providing helpful comments on prior drafts of this Article: William H. Chafe, Steven Lawson, Charles Payne, Sydney Nathans, William Forbath, Regina Austin, Lani Guinier, Richard Marcus, Mary Francis Berry, Kathleen Sullivan, Nancy Marder, Martha Mahoney, Clark Freshman, William Nelson, Reva Siegel, Owen Fiss, Elizabeth Magill, Daniel Nagin, Ben Field, Lisa Campbell, Christine Di Guglielmo, and attendees at presentations held at the William and Mary, Duke, University of Texas, New York University, University of Pennsylvania, University of lllinois, and Washington University law schools. Special thanks to Derrick Bell for inspiration.

'Derrick A. Bell, Jr., Serving Two Masters: Integration Ideals and Client Interests in School Desegregation Litigation, 85 YALE L.J. 470 (1976).

${ }^{2}$ See Bradley v. Milliken, 484 F.2d 215, 242-45 (6th Cir. 1973) (ordering a multidistrict remedy for segregation in city schools), rey'd, 418 U.S. 717, 744-45 (1974) (finding the multidistrict remedy improper absent findings that suburban districts intentionally had committed acts to cause segregation in city schools).

${ }^{3}$ See Calhoun v. Cook, 332 F. Supp. 804, 808-10 (N.D. Ga. 1971) (per curiam) (approving a city-only desegregation plan that minimized pupil integration), aff $d, 522$ F.2d 717 (5th Cir. 1975).

${ }^{4}$ See Morgan v. Hennigan, 379 F. Supp. 410 (D. Mass. 1974) (upholding a desegregation plan that failed to consider the issue of "white flight" and included a substantial amount of busing to achieve integrated schools), aff d sub nom. Morgan v. Kerrigan, 530 F.2d 431 (lst Cir. 1976).

${ }^{5} 347$ U.S. 483 (1954).
} 
quired racially balanced schools even after it had become clear that not only recalcitrant whites but also sympathetic federal judges andmost importantly-their own clients rejected desegregation as the sole remedy for educational inequality. ${ }^{6}$ Bell viewed this rigidity as a function of an ethical tension inherent in LDF's attempts to serve two groups whose interests and objectives diverged: on the one hand were LDF's clients-who suffered the quotidian disadvantages of desegregation, including busing across long distances to schools whose educational merit was often questionable; on the other were LDF's constituents-financial contributors who unfailingly supported the goal of achieving an integrated society.

Though it is a point elided by commentators who emphasize his racial polemics, Bell did not view the "two masters" his article identified solely in terms of race. Serving Two Masters was premised on a war between classes-the rich versus the poor-as well as on the paradigmatic battle of black versus white. More specifically, Bell's article counterposed poor (black) clients against wealthy (mostly white) constituents. In his view, wealthy whites (and a few middle-class black leaders who followed white contributors' lead) were overly influential in LDF's decision making about appropriate remedies in the school desegregation cases. ${ }^{8}$ To resolve this dilemma, Bell suggested that public interest lawyers who represented plaintiffs in school desegregation cases should exercise a great deal of deference to their clients' remedial preferences. In particular, he argued that clients, rather than outsider constituencies, should determine whether integration was an appropriate remedy for educational discrimination.'

This Article challenges Bell's conclusions in important ways while taking seriously, as an analytical matter, the questions of whether and how class conflict affects litigation in race discrimination cases. Most legal commentators who have discussed the constitutional issues pre-

${ }^{6}$ Bell, supra note 1, at 471-72; see also id. at 482-93 (considering these issues in the context of the individual cases).

${ }^{7}$ See id. at 490-91 (defining "clients" as "those on whose behalf" the civil rights attorney brings suit and "constituents" as "those to whom the attorney must answer for his actions" (citing Ronald R. Edmonds, Advocating Inequity: A Critique of the Civil Rights Attorney in Class Action Desegregation Suits, 3 BLACK L.J. 176, 178-79 (1974))).

${ }^{8}$ See id. at 490 ("The lawyers' freedom to pursue their own ideas of right may pose no problems as long as both clients and contributors share a common social outlook. But when the views of some or all of the clients change, a delayed recognition and response by the lawyers is predictable.").

${ }^{9}$ See id. at $489-93$ (arguing that the fee-paying minority in a class action should not control the direction of the suit for all the plaintiffs). 
sented by America's continuing dilemma of race have either overlooked class as an analytical factor or invoked its salience while failing to demonstrate empirically its relevance. Yet the question of how economic disadvantage affects, indeed orders, social relations is an issue that for years has animated scholars in disciplines outside of the law. ${ }^{10}$

In addressing this question here, I use a particular kind of legal history-locally based "sociolegal" history. This approach to legal history combines an analysis of developments in litigation with a detailed discussion of the social dynamics in a single locality in order to highlight nuances overlooked in nationally oriented, case-law-driven legal history. In particular, this methodology uncovers the effect of intraracial, class-based conflict on two fascinating, yet unheralded, civil rights class actions involving the desegregation of Atlanta schools: Calhoun v. Cook and Armour $v$. Nix. ${ }^{11}$ In analyzing the social, political, and economic circumstances surrounding the Atlanta desegregation cases, I seek to demonstrate how locally based sociolegal history can help us more fully understand the human and structural factors that animate the success or failure of legal campaigns against inequality. Specifically, I show that Brown's meaning and practical impact in local jurisdictions did not result only from the actions and opinions of heroic civil rights lawyers and whites-whether judges, lawyers, politicians, or violent resisters to equality-as much legal commentary has implied. Integrating the social history of client-communities into the legal history of the Atlanta school desegregation cases demonstrates that the ideological perspectives and social circumstances of local African

${ }^{10}$ See, e.g., William Julius Wilson, The DeClining Significance OF RaCE 19-23, 134-43 (2d ed. 1980) (arguing that diminished life chances of blacks correlate more highly with economic class position than racism and that the civil rights agenda of the NAACP reflected the values and needs of the black middle class); WILLIAM JULIUS Wilson, The Truly Disadvantaged: The InNer City, the Underclass, and Public POLICY 140-64 (1987) (advocating movement beyond race-specific policies that benefit middle-class blacks to initiatives that address the ills of socially, economically, and geographically isolated blacks living in cities); see also ROBIN D.G. KELLEY, HAMMER AND HoE: ALABAMA COMMUNISTS DURING THE GREAT DEPRESSION (1990) [hereinafter KELLEY, HAMMER AND HOE] (uncovering a history of black workers who identified themselves as oppressed on the basis of class and allied themselves with the Alabama Communist Party rather than civil rights groups such as the NAACP); ROBIN D.G. Kelley, Race Rebels: Culture, Politics, and the Black Working Class (1994) [hereinafter KELLEY, RACE REBELS] (discussing noninstitutionalized forms of resistance to authority and hegemonic norms among working-class minorities).

$"$ Armour v. Nix, Civ. No. 16708, 1979 U.S. Dist. LEXIS 9609 (N.D. Ga. Sept. 24, 1979). 
Americans ${ }^{12}$ influenced the path that Brown took in various communities as well. Brown's putative beneficiaries were not, then, passive recipients of legal strategy and court judgments.

The Atlanta narrative demonstrates, in particular, the social agency of black middle-class decision makers who rejected the integration-oriented remedy favored by LDF over the objections of a group of working-class and poor plaintiff class members. The Calhoun and Armour plaintiff classes were split into multiple opposing camps based on their divergent remedial preferences. Some, including a contingent of working-class and poor plaintiffs, favored using busing as a tool for achieving meaningful pupil integration. Others favored improved schools but did not express a strong or informed opinion about what kind of court order would achieve this goal. Still others, a small group of middle-class black leaders who were supported by local white elites, demanded black administrative control of the school system and a remedy that minimized pupil integration. I argue here that the perspective of this last group, the biracial elite, prevailed in the courts largely because presiding judges did not meaningfully address the reality that poor blacks had interests distinguishable from those of the middle-class blacks who were the self-proclaimed leaders of the entire African American community. The Atlanta narrative thus reveals the relevance of intraracial social dynamics, particularly class dynamics, to effective public interest lawyering and to effective remedies for constitutional violations.

The remainder of this Article is divided into four parts. Part I explores how and why the legal literature that considers the issue of school desegregation generally omits discussions of intraracial, classbased conflict. I demonstrate that by privileging white resistance and doctrinal concepts, legal scholars have offered an incomplete analysis of the factors that undermined civil rights lawyers' efforts to implement Brown and, by analogy, the problems that beset other efforts to reform society through law.

In Part II, I offer empirical support for the claim that scholarship on Brown's implementation is incomplete because it fails to consider intraracial dynamics. I analyze the legal and political maneuvering that led to the settlement of the Atlanta school desegregation cases in a manner that a vocal contingent of working-class and poor plaintiffs found inadequate. I draw upon transcript testimony of hearings held Article.

${ }^{12}$ I use the terms "black" and "African American" interchangeably throughout this 
by the federal district court to entertain objections to the settlement as well as other evidence to demonstrate that socioeconomic class was a factor salient in lawyers', politicos', and nonlawyers' deliberations about the settlement. Class consciousness and class interests influenced the substantive provisions of the settlement, the extent to which and manner in which the proposed settlement was discussed by lawyers and clients, and clients' perceptions of the settlement's efficacy. A further point here is that the law-its norms, rules, and procedures-was constitutive in decision makers' ability to attain a remedy that favored the preferences of the black middle-class leadership and delegitimized the concerns of the black working poor.

In Part III, I discuss the normative implications of the historical analysis offered in the previous sections of the Article. These implications relate to scholarly assessments of the significance of Brown $v$. Board of Education and Swann v. Charlotte-Mecklenburg Board of Education, ${ }^{13}$ the utility of the sameness norm relied on to settle disputes in equal protection jurisprudence, and the power of empirically based social history to inform the continuing debate about whether significant social reform can be achieved through law. I conclude by challenging scholars, public interest lawyers, and courts to account for the multidimensionality of plaintiffs in civil rights actions when considering, litigating, and adjudicating their constitutional claims.

\section{AGAINST EXCEPTIONALISM IN LEGAL UNDERSTANDINGS OF RACE}

One of the most provocative concepts in labor history is "American exceptionalism," the notion that class consciousness was relatively undeveloped among the working classes in the United States when compared to the working classes of Europe. ${ }^{14}$ American labor historians have worked assiduously over the years to correct the exceptionalism misconception. Through research projects focused both on activities within trade unions and without, these historians have uncovered a history of working-class culture and consciousness among Americans, including vibrant stories of workers organizing collectively to demand safer workplaces, more competitive wages, and union rep-

\footnotetext{
13402 U.S. 1 (1971).

14 For a discussion of American exceptionalism, see LEON FINK, Looking Backward: Reflections on Workers' Culture and Certain Conceptual Dilemmas Within Labor History, in IN SEARCH OF THE WORKING CLASS 175 (1994).
} 
resentation. ${ }^{15}$ Much of this scholarship explores the class consciousness of African American workers, women, and others not traditionally perceived as legitimate wage earners. ${ }^{16}$ The persuasive power of these works lies in their painstakingly detailed descriptions of associations, habits, behaviors, and acts of protest that elucidate the experiences of the working classes-their cultures, communities, beliefs, and organizations.

I propose that a variant of the "exceptionalism" idea functions within the legal literature addressing race-related equal protection jurisprudence, and that this idea needs to be corrected by similarly detailed historical analysis. This "exceptionalism" functions to disregard the existence of class (and other) differences among African Americans, to obscure significant differences in African Americans' lived experiences that are related to these class differences, and to neglect the possibility that such class (and other) differences might lead to distinct, perhaps even competing, perspectives on public policies and

${ }^{15}$ See, e.g., William E. Forbath, LAW AND the SHAPING OF THE AMERJCAN LABOR MOVEmENT 3-36 (1991) (outlining the American labor movement in the late nineteenth and early twentieth centuries, and analyzing the law's considerable influence on labor conflicts during that period); Herbert G. GUTMAN, WORK, Culture, AND SOCIETY IN INDUSTRIALIZING AMERICA (Vintage Books 1977) (1966) (exploring the beliefs and behavior of working-class Americans during the nineteenth century); DAVID MONTGOMERY, WORKERS' CONTROL. IN AMERICA (1979) (contemplating the control position of the American worker against the backdrop of increasing demands for rising productivity); LEON FINK, The New Labor History and the Powers of Historical Pessimism: Consensus, Hegemony, and the Case of the Knights of Labor, in IN SEARCH OF THE WORKING Class, supra note 14, at 89, 90-91 (arguing that "the history of the Knights of Labor ["the largest and most representative labor body until its time"] demonstrates the existence of a viable labor culture").

${ }^{16}$ For examples of literature that subverts the exceptionalism myth, see HERBERT HILL, BLACK LABOR AND THE AMERICAN LEGAL SYSTEM (1985); DOLORES E. JANIEWSKI, SISTERHOOD DENIED: RACE, GENDER, AND CLASS IN A NEW SOUTH COMMUNITY (1985); David M. KaTZMan, SEven DaYs a WeEk: WOMEN AND DOMESTIC SERVICE IN Industrializing america (1978); Nell IRVIN Painter, The Narrative of Hosea HudSon: His Life as a NEgro COMMUNist in THE SOUTH (1979); PETER J. RachlefF, BLACK LABOR IN RICHMOND, 1865-1890 (Illini Books 1989) (1984); JOE WILLIAM TrotTer, JR., BlaCk MilwaukEe: THE Making, OF AN INDUStrial Proletariat, 191545 (1985). For a study of the indispensable contribution enslaved people made to "the development of black culture and black national consciousness as well as to American nationality as a whole," see EUGENE D. GENOVESE, ROLL, JORDAN, ROLL: THE WORLD THE SLAVES MADE, at xvi (1974). More recent works relevant to the myth of exceptionalism include TERA W. HUNTER, TO 'JOY MY FREEDOM: SOUTHERN BLACK WOMEN'S LIVES AND LABORS AFTER THE CIVIL WAR (1997); KELLEY, HAMMER AND HOE, supra note 10; KELLEY, RACE REBELS, supra note 10. 
laws that impact African Americans based on their racial categorization. ${ }^{17}$

The scholarly literature on the implementation of Brown is especially revelatory of this phenomenon. A narrow, racial understanding of African American plaintiffs' interests was to be expected in the earlier years of commentary about the case, given that the right at issue was the dismantling of de jure racial segregation in schools. Legal commentators' failure to consider the remedial consequences of intraracial conflict later on-after the problems attendant to implementing the decree became clear-is less understandable and less justifiable.

Scholars' failure to take up Bell's challenge in Serving Two Masters to consider the relevance of class to LDF's decision making in school desegregation suits is indicative of their failure to confront the question of how social dynamics within African American communities affect social policy and legal strategy. This is not to say that Bell's article was completely ignored. Quite the contrary is true. Following its publication, a generation of scholars discussed and debated many of the themes that Bell discussed in Serving Two Masters, but they did so chiefly in terms of constitutional law and theory-hence, abstractly rather than empirically. Both conservative commentators ${ }^{18}$ and leftist critical theorists ${ }^{19}$ questioned the efficacy of litigation as a tool for

${ }^{17}$ In using the term "class," I mean not only to refer to relations between individuals of different economic levels-that is, those with lesser, versus those with greater, wealth, skills, goods, and services-but also to membership in social status groups. See MAX WEBER, Wirtschaft und Gesellschaft [Economics and Society], in FrOM MAX WEBER: ESSAYS IN SOCIOLOGY 180, 181-82 (H.H. Gerth \& C. Wright Mills trans. \& eds., 1948) (1921) (stating that the economic order and the social order are distinct concepts, but both are related to the distribution of power within a community). Although social status and privileged economic-class standing are related concepts, wealth and status do not necessarily correlate, especially within African American communities, where professionals (e.g., secondary school educators) not of great wealth historically have been accorded considerable social status. See, e.g., Tomiko Brown-Nagin, The Transformation of a Social Movement into Law? The SCLC and NAACP's Campaigns for Civil Rights Reconsidered in Light of the Educational Activism of Septima Clark, 8 WOMEN'S HIST. REV. 81, 115, 132 n.66, 136 n.97 (1999) (discussing the status of African American teachers and other professionals). See generally E. FrankLIN FrazIER, BLACK BOURGEOISIE 43-59 (1957) (detailing the statistical breakdown of black, middleclass, white-collar employment and black-owned businesses).

${ }^{18}$ See, e.g., ThOmas Sowell, Civil Rights: RHETORIC OR REALITY? $61-86$ (1984) (arguing that cases implementing Brown were ill-conceived and counterproductive).

19 See, e.g., Duncan KENNEdy, LEgal Education and THE REPROduction OF Hierarchy: A POLEMIC AGAINST THE SySTEM 1-20 (1983) (suggesting that legal reasoning is a form of argumentation that does not address the legitimacy of social, political, and economic outcomes that legal decisions authorize); ROBERTO MANGABEIRA 
achieving large-scale social change of a countermajoritarian nature. Legal ethicists and civil proceduralists evaluated whether the Model Rules of Professional Responsibility and doctrine governing the lawyer/client relationship adequately protect the interests of the many parties who may be affected by class action litigation. ${ }^{20}$ And constitutional scholars considered whether the Court's antidiscrimination doctrine requires the full-scale restructuring of public institutions guilty of practicing racial discrimination in the past or merely demands the establishment of prophylactic rules to protect against future discrimination. $^{21}$ In focusing on these matters, this generation of

UNGER, THE CRITICAL LEGAL STUdies MOVEMENT 15-42 (1986) (deconstructing notions of objective legal analysis and arguing that legal norms preserve dominant interests); Mark Tushnet, An Essay on Rights, 62 TEx. L. REv. 1363, 1363-94 (1984) (insisting that rights are indeterminate and antithetical to causes that seek fundamentally to restructure society); see also GERALD N. RosEnBERG, THE Hollow Hope: CAN COURTS BRING ABOUT SOCIAL CHANGE? (1991) (proposing, on the basis of empirical data, that seminal Supreme Court decisions in areas such as civil and women's rights impeded significant social reform rather than produced major change); cf. Kimberlé Williams Crenshaw, Race, Reform, and Retrenchment: Transformation and Legitimation in Antidiscrimination Law, 101 HARV. L. REV. 1331, 1376-81 (1988) (arguing that antidiscrimination law relies on ambiguous norms suggesting a symbolic commitment to equality while producing ephemeral results that neglect material disadvantage and threaten the political consciousness of minority groups).

${ }^{20}$ See, e.g., DAVId LuBAN, LAWYERS AND JUSTICE: AN ETHICAL STUdY 341-57 (1988) (discussing the ethical problems inherent to representing divided class members in a class action suit); Samuel Issacharoff, Governance and Legitimacy in the Law of Class Actions, 1999 SUP. CT. REv. 337, 349-67 (addressing doctrinal avenues for protecting the interests of class members in a mass tort context); Deborah L. Rhode, Class Conflicts in Class Actions, 34 STAN. L. REV. 1183, 1191-221 (1982) (postulating that full disclosure of conflict, but not necessarily deference to plaintiffs' preferences, could enhance adequacy of representation); William B. Rubenstein, Divided We Litigate: Addressing Disputes Among Croup Members and Lawyers in Civil Rights Campaigns, 106 YALE L.J. 1623 (1997) (discussing ways that procedural and ethical rules could promote group decision making to settle conflicts in class actions); Patrick Woolley, Rethinking the Adequacy of Adequate Representation, 75 TEX. L. REV. 571, 573 (1997) (arguing that "every class member whose . . . identity can be reasonably ascertained has a constitutionally protected right to prosecute his cause of action by presenting evidence and making legal arguments not otherwise before the court," and that allowing each class member to intervene as a party "has the potential to significantly improve the quality of representation afforded" to all class members).

${ }^{21}$ This discussion first took place around the issue of school desegregation and then moved to the issue of affirmative action for women and minorities in education and employment. See, e.g., Paul Gewirtz, Choice in the Transition: School Desegregation and the Corrective Ideal, 86 ColuM. L. REV. 728, 731-49 (1986) (comparing and contrasting prophylactic norms with antidiscrimination rules that require dishonoring of individuals' preferences not to attend desegregated schools); Gary Peller, Race Consciousness, in AFTER IDENTITY 67, 76-80 (Dan Danielsen \& Karen Engle eds., 1995) (describing the cultural origins of the conflict over the advisability and proper focus of affirmative action). 
legal scholars neglected a sustained discussion of Bell's suggestion that a relationship existed between socioeconomic status and the remedial outcomes preferred by LDF's clients, as opposed to those preferred by its constituents. ${ }^{22}$

Furthermore, when Bell's work inspired commentary, legal scholars analyzed the constitutional, procedural, ethical, and theoretical dilemmas posed by LDF's effort to implement Brown solely in terms of race. In doing so, these scholars made race an overdetermined category of analysis. For example, constitutional scholars' prescriptions for implementation of Brown focused on the appropriate doctrinal responses to white resistance. ${ }^{23}$ Implicitly or explicitly, these scholars assumed the existence of a unified plaintiff class and appreciated the conflict in school desegregation actions as between the races-the white racists, on the one hand, and the African American victims, on the other. ${ }^{24}$ More surprising is the tendency of critics of liberal legal scholarship, whether critical theorists or critical race theorists, to give little sustained analytical or descriptive attention to the matter of how, specifically, legal norms and ideology legitimate the class structure and exacerbate racial disadvantage.

${ }^{22}$ Bell did not substantiate this claim himself, but he cited with approval social scientist Ron Edmonds's proposition that LDF lawyers' efforts to serve their clients were hamstrung by middle-class whites and blacks who refused to reexamine the organization's policy of advocating school integration, notwithstanding the alleged costs of the practice to its putative beneficiaries. Bell, supra note 1, at 490-91; see also supra note 7 and accompanying text (discussing the disparity between clients' and constituents' goals).

2.3 See, e.g., Paul Gewirtz, Remedies and Resistance, 92 YALE L.J. 585, 608-65 (1983) (proposing judicial responses to, and compromises with, white resistance to desegregated schools); James S. Liebman, Implementing Brown in the Nineties: Political Reconstruction, Liberal Recollection, and Litigatively Enforced Legislative Reform, 76 VA. L. REv. 349, 360-70 (1990) (suggesting a reorientation of political processes so that white resistance to desegregation would be understood to harm public interest generally, rather than to infringe individuals' private interests).

${ }^{24}$ At Bell's prompting, some scholars acknowledged that some African Americans, like many whites, opposed desegregation of the schools. These scholars failed, however, to grapple with this conflict analytically. See, e.g., Gewirtz, supra note 23, at 594-95 (understanding differences of opinion among black plaintiffs in school desegregation class actions as being indicative of "unavoidable remedial imperfection").

${ }^{25}$ While critical theorists contend that legal ideology and rights consciousness legitimate the social order, their focus on rhetoric has not generated a sustained analysis of how legal norms validate specific social phenomena in which class relations are implicated. See, e.g., Tushnet, supra note 19, at 1364, 1398-403 (arguing that law protects the interests of the privileged, but defending his critique of rights against the "workingclass rejoinder" that some rights, such as the collective bargaining structure, are important and effective for laborers); cf. MORTON HORWITZ, THE TRANSFORMATION OF AMERICAN LAW, 1780-1860, at 1-30 (Oxford Univ. Press 1992) (1977) (asserting that 
One reason for legal scholars' staunch allegiance to a narrow, racialist understanding of the constitutional problems associated with the school desegregation issue is the fact that the most notorious cases were predicated on the Deep South archetype. These cases arose in locales where racial lines were drawn so tightly and whites were so intransigent to racial change that differences among African American plaintiffs were obscured. In these places, the activities of local white racists dominated contemporaneous accounts of developments in school desegregation cases.

Little Rock was such a locale. The dramatic events that occurred there-the violent resistance of whites to nine young blacks, dressed in their Sunday best, attempting to integrate the high school, and the subsequent arrival of National Guard troops to protect the black students as they entered the school-served as a basis, not only in the public imagination but also within legal academia, for theorizing about the constitutional issues presented by the effort to implement Brown. ${ }^{26}$ Similarly, the most famous incidents in the public memory of the direct action phase of the Civil Rights Movement-Bull Connor's

changes in common law rules advanced the interests of powerful elites, but focusing on trends in doctrine rather than on the social history of non-elites whose interests were not advanced by changes in the law). On the critical theorists' failure to discuss issues of race to the extent favored by critical race scholars, see Crenshaw, supra note 19, at 1356-66. See also José A. Bracamonte, Foreword to Symposium, Minority Critiques of the Critical Legal Studies Movement, 22 HARV. C.R.-C.L. L. REV. 297, 298 (1987) (stating that the critical legal studies movement has "failed to comprehend, assess, and respond to the reality of minorities in this country").

Some critical race theorists mention class as a salient factor in critiquing antidiscrimination discourse, but they do not make class a central factor in their analyses. See, e.g., Derrick Bell, FACES at THE BotTom of THE Well: THE PERMANEnCE of Racism 3-12 (1992) (noting the income gap between whites and blacks, but citing inadequate legal redress of white racism as the cause of continued subordination of African Americans); Kimberle Crenshaw, Mapping the Margins: Intersectionality, Identity Politics, and Violence Against Women of Color, 43 STAN. L. REV. 1241, 1242 (1991) (acknowledging that class shapes the experiences of women of color, but focusing only on the gender and racial dimensions of their experiences); Crenshaw, supra note 19, at 1378-79 (recognizing that the elimination of state-enforced discrimination affected blacks differently depending on their "material disadvantage"); Neil Gotanda, A Critique of "Our Constitution Is Color-Blind," 44 STAN. L. REV. 1, 36-52 (1991) (arguing that constitutional discourse on race fosters white domination in social, economic, and political arenas by identifying distinct themes about the meanings of race in discrimination cases). But of. Patricla J. Williams, The Alchemy OF RaCE AND Rigitss 22-28 (1991) (arguing that norms embedded in criminal and administrative law and doctrine applied in interpreting the Equal Protection Clause fail to address concrete daily dilemmas of homeless or impoverished blacks).

${ }^{26}$ See generally Gewirtz, supra note 23, at 614-17 (discussing the proper judicial response to white resistance to school desegregation). 
resistance to the desegregation of public facilities in Birmingham, white mobs' mauling of students who attempted to desegregate interstate transportation during the "Freedom Rides," the Montgomery church bombing-involved violent resistance to civil rights campaigns. ${ }^{27}$ The trend in scholarship and among commentators to rely on this paradigm was encouraged when, even in the putatively more racially liberal North, the most famous desegregation case-the Boston litigation-conformed to the archetype, with whites from South Boston replacing whites from the Deep South as antagonists.

Since scholars routinely extrapolated from this violence-inflected racial paradigm to make points about law and American race relations, it is not surprising that legal reasoning about race has not focused on subtleties such as intraracial dynamics. Nevertheless, this Article takes the position that the elision of intraracial social dynamics, including class differences, as a topic of scholarly analysis should not of necessity follow from the continuing reality of white resistance to black equality. ${ }^{29}$

There is another, complementary explanation for legal scholars' failure to grapple analytically with class. Legal doctrine overdetermines understandings of the nature of the right to equal protection and appropriate remedies for denial of this right. In other words, the literature's racial reductionism follows from the central doctrinal conventions of constitutional law. In particular, this reductionism flows from the reality that while race is deemed a suspect classification in constitutional jurisprudence, ${ }^{30}$ wealth is not $^{31}$ (although equal protec-

27 See generally ADAM FaIRclough, TO REDEEM THE SOUL OF AMERICA: THE SOUTHERN CHRISTIAN LEADERSHIP CONFERENCE AND MARTIN LUTHER KING, JR. 57-84, $111-40,225-52$ (1987) (describing these three incidents).

${ }^{28}$ See Ronald P. Formisano, Boston AGAinst BuSING: RACE, Class and ETHNICITY IN THE 1960S AND 1970s, at 114-15, 122-24, 143-45, 150, 153, 161, 185-86, 204-05, 212, 228 (1991) (depicting the Boston riots as the result of racial and class conflict).

${ }^{29}$ See JenNifer L. HOCHSChILD, THE NEW AMERICAN DILEMma: Liberal DEMOCRACY AND SCHOOL DESEGREGATION 18, 22, 27-30, 180 (1984) (discussing white attitudes toward desegregation); RAYMOND WOLTERS, THE BURDEN OF BROWN: THIRTY YEARS OF SCHOOL DESEGREGATION 16-1 7, 42-43, 94-96, 158-61, 169, 173, 175, 182, 19396, 203, 205, 239-40, 246-48 (1984) (chronicling white flight associated with desegregation from which the consolidated cases known as Brown $v$. Board of Education arose).

${ }^{30}$ See Korematsu v. United States, 323 U.S. 214, 218-19 (1944) (pronouncing racebased classifications "suspect," but upholding the internment of people of Japanese ancestry during World War II on the basis of war powers).

${ }^{31}$ See San Antonio Indep. Sch. Dist. v. Rodriguez, 411 U.S. 1, 18 (1973) (rejecting a claim that a state's school-financing system resulting in immense disparities in perpupil funding between richer and poorer districts violated the Constitution). 
tion and due process protections are afforded to indigents who are subject to the deprivation of government benefits ${ }^{32}$ or penalties of a criminal nature). ${ }^{33}$ Since class is not recognized as relevant to adjudicatory and interpretative norms in the doctrine, commentators have ignored the relevance of class relations to the social realities of litigants, including racial minorities. ${ }^{34}$

Whatever the reasons for the analytical oversight, the legal literature's exceptionalism is mistaken. In reifying the doctrinal fiction that wealth is an inconsequential category of analysis, the legal literature obfuscates a social relation that greatly constrains the life choices of the doctrinally recognized suspect racial classes. Given the role of socioeconomic status in marking an individual's place in the social hierarchy and poverty's role in African Americans' oppression historically, it is critical that legal scholars and historians consider the relevance of class in a variety of contexts, including the civil rights class action.

\section{A Contested SeTtlement}

Bell's Serving Two Masters, while seminal in the legal literature for its suggestion that the socioeconomic status of LDF's constituents overwhelmed its clients' remedial preferences, mischaracterized the nature of the impact of class relations on the legal decision-making process. Bell's thesis was premised on his opposition to further efforts by LDF to seek remedies primarily focused on pupil integration. This Article's detailed analysis of social and economic dynamics in one of

32 See, e.g., Goldberg v. Kelly, 397 U.S. 254, 261 (1970) (ruling. that welfare payments may not be terminated without a pretermination hearing); of. Goss v. Lopez, 419 U.S. 565, 574 (1975) (holding that, where a state has established a system of free public education, an enrolled student may not be dismissed from school for disciplinary reasons without a fairness hearing).

${ }^{33}$ See Mayer v. City of Chicago, 404 U.S. 189, 195 (1971) (deciding that transcript fees may not impede indigent criminal defendants' rights to defend themselves); Douglas v. California, 372 U.S. 353, 357 (1963) (holding that equal protection is violated when an indigent defendant appears without counsel in her first appeal of a criminal conviction).

${ }^{34}$ This is not to say that scholars have not suggested affirmative doctrinal recognition of socioeconomic disadvantage; some have, most notably during the $1970 \mathrm{~s}$. See, e.g., Frank I. Michelman, On Protecting the Poor Through the Fourteenth Amendment, 83 HARV. L. REV. 7, 38-39 (1969) (arguing that courts should guarantee each person a minimum allocation for her basic needs). See generally Owen M. Fiss, Groups and the Equal Protection Clause, 5 PHL. \& PUb. AFF, 107, 171 (1976) (advocating a "group disadvantaging principle" that would take better account of the social realities of those protected by the Equal Protection Clause than conventional antidiscrimination norms and doctrine). 
the three cities cited by Bell as evidence for his conclusions suggests, however, that his argument lacked empirical support in important respects.

LDF's effort to implement Brown v. Board of Education in Atlanta was cut short in 1973 when the local NAACP president and a few other middle-class African American leaders decided to settle Calhoun $v$. Cook. ${ }^{35}$ The black elite negotiated the settlement with a group of white business and civic leaders but without the knowledge or consent of either the majority of plaintiff class members or their attorneys of record since 1958, LDF. $^{36}$

The history of this settlement complicates the narrative of interracial cohesion suggested by Bell and recapitulated time and again in the legal literature. Deep divisions existed among LDF's clients regarding the remedy to be pursued, as well as between leaders of the local NAACP, on the one hand, and the national NAACP and NAACP LDF, on the other. The end result was a plaintiff class divided in many ways, including along class lines, with each camp aligned with separate and competing groups of lawyers.

The historical evidence uncovered in this Article suggests that Bell was at once correct and incorrect in his assessment of the relevance of class to decision making in the school desegregation cases. Bell's contention that certain school desegregation actions involved conflict and ethical dilemmas related to the socioeconomic statuses of decision makers and clients was correct. Nevertheless, the historical record supports a correlation between remedial preferences and class that is significantly different from, and indeed in some ways the opposite of, that supposed by Bell.

The Atlanta example reveals that both the working-class and middle-class African Americans (and whites) who participated in the Atlanta litigation demonstrated "double consciousness"-both racial and class consciousness-rather than a monolithic racial perspective on appropriate strategies, tactics, and remedies. ${ }^{37}$ Working-class cli-

${ }^{35} 451$ F.2d 583 (5th Cir. 1971) (per curiam).

${ }^{36}$ See infra Part II.B (describing the settlement negotiations).

${ }^{37}$ The allusion to "double consciousness" is a play on W.E.B. Du Bois's words from his classic work, The Souls of Black Folk, in which he wrote:

It is a peculiar sensation, this double-consciousness, this sense of always looking at one's self through the eyes of others .... . One ever feels his twoness[] -an American, a Negro; two souls, two thoughts, two unreconciled strivings; two warring ideals in one dark body, whose dogged strength alone keeps it from being torn asunder. 
ents did not uniformly oppose racial-balance orders, and school integration was not advocated and imposed by a unified group of middleclass decision makers from outside of the city. ${ }^{38}$ Moreover, the conflict that marred the proceedings in Calhoun was not only between lawyers and clients but also among members of the plaintiff class, as well as between LDF lawyers and lawyers hired by the local NAACP chapter to subvert LDF's racial-balance plan. Power relations of various sorts were at work; hence, this was not solely the paradigmatic battle of whites against blacks and rich versus poor that Bell implied.

Bell was most misguided in his assumption that middle-class blacks influenced LDF to support racial-balance orders on the basis of a blind faith in the ideology of integration. In Atlanta, middle-class blacks and whites tended to oppose rather than support desegregation of schools. ${ }^{99}$ They did so to protect black middle-class employment interests and to preserve a select group of segregated, but highly regarded, schools that catered to the children of Atlanta's African American elite. Furthermore, to the extent that the African American leadership offered an ideological justification for their remedial preferences, it was black nationalist rather than integrationist. The leaders opposed a remedy focused on pupil integration because of their faith that black educators and administrators could ameliorate educational problems in all-black schools without whites' involvement in school governance matters.

Bell also was incorrect in his assumption that the working class and poor embraced a simple and uniform solution to the problem of inferior schools. Opinions among working-class members of the plaintiff class were not uniform. The working class tended either to support LDF's desegregation plan, to be critical of all legal processes and skeptical of the efficacy of legal norms to improve the quality of black students' educational opportunities, or to be unaware of, or not to voice an opinion about, the settlement at all. ${ }^{40}$ The working class

W.E. BuRghardT Du BoIS, The SOUls of Black Folk 3 (7th ed., A.C. McClurg \& Co. 1907) (1903). Whereas Du Bois's "double consciousness" referred to the psychic weariness created by slavery and segregation, I use the term to refer to the interplay of race- and class-based disadvantage and its impact on the African American working class and poor.

${ }^{38}$ See infra Part II.B.2, D.2-3 (addressing varied working-class and upper-class opinions of the settlement, and describing the settlement's negotiators).

${ }^{39}$ See infra Part II.D.2-3 (relating the testimony of various Atlanta residents in support of and in opposition to the Calhoun settlement).

${ }^{40}$ See infra Part II.D.4 (noting the low rate of black Atlantans' participation in the settlement hearings and the reasons for their silence). 
and poor thus held varied opinions, and many were disaffected from and uninvolved in the legal process.

Nevertheless, the Atlanta narrative reveals intraracial tension about the school desegregation issue that was predicated in part on class consciousness. Specifically, civil rights lawyers' efforts in Atlanta were constrained by the assumption of local middle-class black elites that they should determine the appropriate tactics, strategies, and goals of the campaign to implement Brown. ${ }^{41}$ Neither lawyers from New York nor local African Americans would alter the elites' determination, forged by their identity as the "Talented Tenth," to control the terms and conditions under which the entire black community would experience law's equal protection in the realm of public education. ${ }^{42}$ Theirs was a considered judgment held for many years.

Beginning in the years following World War II, a small group of Atlanta's middle-class black population determined that politics was a particularly fruitful avenue for addressing civil rights concerns. Indeed, the black elite preferred resolving racial problems through privately negotiated settlements, or "gentlemen's agreements," with the white elite and through the electoral process. ${ }^{43}$ In particular, the elite placed great faith in the efficacy of bloc voting in mayoral elections. After influencing which candidate won the mayoralty, the African American elite would then work behind closed doors to put pressure on him and other municipal officials to ameliorate problems faced by blacks, such as shortages in housing, inadequate healthcare, and inferior schooling. They viewed formal legal processes as secondary to these formal and informal political processes as tools for mediating racial disputes. ${ }^{44}$

As a result of the black elite's allegiance to this combination of formal and informal politics as the primary means of achieving civil

4] See infra notes 85 and accompanying text (discussing the decision of the selfappointed leaders to hold settlement negotiations in secret).

${ }^{42}$ See W.E.B. Du Bois, The Talented Tenth, in The Negro Problem 33, 33 (AMS Press 1970) (1903) ("The problem of education, then, among Negroes must first of all deal with the Talented Tenth; it is the problem of developing the Best of this race that they may guide the Mass away from the contamination and death of the Worst, in their own and other races.").

${ }^{43}$ See Tomiko Brown-Nagin, Class Actions: The Impact of Black and Middle-Class Conservatism on Civil Rights Lawyering in a New South Political Economy, Atlanta, 1946-1979 ch. 2 (2002) (unpublished Ph.D. dissertation, Duke University) (on file with the Duke University Library) (discussing the "Atlanta style of biracial negotiation" and its impact on the pace and nature of the civil rights movement in Atlanta).

See id. at 46-56 (describing African Americans' voting efforts in Georgia and their effects on Georgia politics). 
rights gains, law was not the primary means through which public values regarding race relations were shaped in post-War Atlanta, including during the most critical phases of the civil rights movement. This reality was a crucial determinant of the path taken by LDF's campaign to implement Brown in Atlanta. The perceived commonality of identity and interests between members of the black and white middle classes, or within the "biracial elite"-in particular, the members" preference for using negotiated settlement to address race-related disputes-undermined the willingness and ability of LDF's clients to contest racial inequality through the courts. Ultimately, the extralegal processes favored by the elite served to delay or impede social change through law. This was true even after the Supreme Court issued decisions that empowered federal courts to become increasingly proactive in dismantling segregated schools, as the following sections show.

\section{A. Swann v. Charlotte-Mecklenburg Board of Education as the Precipitate for Settlement}

In Swann v. Charlotte-Mecklenburg Board of Education, ${ }^{45}$ the Supreme Court addressed the question of how school districts should comply with their obligation to operate unitary schools in large urban school systems where freedom-of-choice plans were inadequate to achieve desegregation and residential segregation was endemic. Justice Warren Burger's opinion for the Court in Swann established a presumption that single-race schools were unconstitutional ${ }^{46}$ and articulated the view that federal judges possessed broad equitable powers to issue remedial orders to achieve desegregated schools. ${ }^{17}$ In particular, the unanimous Court endorsed the use of racial ratios in formulating desegregation plans and, recognizing the relationship between residential and school segregation, held that officials could gerrymander school attendance zones and bus students between noncontiguous attendance zones to achieve pupil integration. ${ }^{48}$ As a result of Swann,

45402 U.S. 1 (1971).

${ }^{46}$ See id. at 18 ("Independent of student assignment, where it is possible to identify a 'white school' or 'Negro school' simply by reference to the racial composition of teachers and staff ... a prima facie case of violation of substantive constitutional rights under the Equal Protection Clause is shown.").

${ }^{47} \mathrm{Id}$. at $16-17$.

${ }^{48} I d$. at 16-19, 25-32. For a discussion of the negotiations among the Justices that occurred during the process of formulating the Court's final opinion in Swann, see Davison M. Douglas, Reading, Writing, and Race: The Desegregation of the CHARLOTTE SCHOOLS 206-14 (1995). 
federal district court judges ordered school systems across the South to use the tools legitimated in the case-specifically busing and rezoning-to achieve pupil integration. ${ }^{49}$

Swann posed significant difficulties for Atlanta's biracial leadership. These leaders had assumed that by submitting to a voluntary desegregation plan, one based on students' preferences as to where to attend school, they had met their obligation to comply with Brown. In their minds, Atlanta had weathered the school desegregation crisis with the city's reputation for racial progressiveness and the traditional patterns of segregation in schools and residential areas intact. ${ }^{50}$ Swann threatened the biracial leadership's assumption that Atlanta had emerged unscathed by the turbulence experienced in other cities.

As a result, a biracial group of business and civic leaders, only one of whom was a plaintiff in the desegregation suit but most of whom were defendants, determined to respond to Swann in a manner that would head off the possibility that the decision would unravel the city's relative racial equanimity. The group achieved its goal in two steps: first, through a series of legal maneuvers that disavowed the significance LDF attributed to Swann and delayed the implementation of a new desegregation plan consistent with it; and second, by agreeing to settle the case in a manner that allowed the city to avoid complying with Swann altogether. ${ }^{51}$

49 See Douglas, supra note 48, at 212 ("McMillan's order became a benchmark that many other federal judges sought to emulate."); see also JACK GREENBERG, CRUSADERS IN THE COUR'TS 388-89 (1994) (relating the author's post-Swann filings of Swann motions in all pending cases and recognizing that "thoroughgoing desegregation became widespread").

50. Susan M. McGrath, Great Expectations: The History of School Desegregation in Atlanta and Boston, 1954-1990, at 219 (1992) (unpublished Ph.D. dissertation, Emory University) (on file with author); see Edward Peeks, Significance of Decision Aired by City Leaders, ATLANTA DAILY WORLD, May 18, 1954, at 1 (recognizing that the current housing situation would "tend to hold Negro students in schools in their communities and whites in theirs"); Segregation to Continue, School Officials Predict, ATLANTA DAILY WORLD, May 18, 1954, at 1; see also Samuel Adams, Housing Cited as Factor in School Desegregation, ATLANTA DAILY WORLD, Nov. 10, 1955, at 1 ("[H]ousing is and will coninue to be the controlling factor that will keep the schools separate for a long time."). On policies that resulted in and perpetuated residential segregation in Atlanta over time, see RONALD H. BAYOR, RACE AND THE SHAPING OF TWENTIETH-CENTURY ATLANTA $53-85,235,237,245,251$ (1996).

${ }^{51}$ See infra Part II.B-E (discussing the settlement, its terms, the questionable circumstances leading to it, and various reactions to it). 
In view of Swann, LDF appealed an earlier finding by the federal district court that Atlanta's school system was unitary ${ }^{52}$ and prevailed. In an October 10, 1971, order, the Fifth Circuit Court of Appeals vacated the district court's order finding unitariness and ordered the court to allow the plaintiffs a reasonable opportunity to present a desegregation plan that utilized the desegregation techniques sanctioned in Swann."

On December 30, 1971, LDF submitted its desegregation plan to the district court. LDF's plan was aimed at remedying statistics showing that, in 1971, 42.4\% of Atlanta's elementary students and $50.7 \%$ of its high school students attended schools in which $99 \%$ of the students were of the same race. These statistics were partly a result of spatial segregation: whites lived at the northern and southern ends of the city whereas African Americans lived in a broad middle section of Atlanta. ${ }^{54}$ LDF's plan eliminated all one-race schools in the district using all of the Swann techniques. ${ }^{55}$ Given the extent of "white flight" from the city, however, the ratios of African American students in many schools were high even under LDF's plan. For instance, under LDF's proposal, the student body of the Harper Elementary School would be 84.9\% African American. ${ }^{56}$ Even where noncontiguous schools were grouped, the percentage of blacks in the student body ranged from $66 \%$ to $80 \%$ under LDF's approach. ${ }^{57}$ Thus, the effect of LDF's pro-

${ }^{52}$ See Calhoun v. Cook, 332 F. Supp. 804, 809 (N.D. Ga. 1971) (finding no evidence of de jure segregation and therefore determining that "[i]t appears to be a unitary system "within which no person is effectively excluded from any school because of race or color'" (quoting Alexander v. Holmes County Bd. of Educ., 396 U.S. 19, 20 (1969) (per curiam))).

${ }^{53}$ Calhoun v. Cook, 451 F.2d 583, 583-84 (5th Cir. 1971) (per curiam); see BAYOR, supra note 50, at 244-45 (noting the Fifth Circuit's reversal of the district court's finding that Atlanta "had done all that it could" except for large-scale busing); $c f$. Calhoun, 332 F. Supp. at 809-10 (addressing the applications of Swann utilized to date and the additional need "for a sweeping examination of its relationship to housing, planning, finances, rapid transit and all the other external factors which vitally affect [public education's] role in the community").

${ }^{54}$ Calhoun, 332 F. Supp. at 806.

${ }^{55}$ See supra notes 45-49 and accompanying text (discussing Swann's holding that single race schools were unconstitutional and federal judges had broad equitable powers to issue remedial orders).

${ }^{56}$ See Plaintiffs' Motion for Adoption of Plaintiffs' Proposed Desegregation Plan and for Other Relief, at app. ser. I, Calhoun v. Cook, 362 F. Supp. 1249 (N.D. Ga. 1973) (No. 6298) (on file with National Archives \& Records Administration, Wash., D.C. (NARA), case file, box 55, folder 3) [hereinafter Plaintiffs' Proposed Desegregation Plan] (charting the racial composition of certain elementary schools under the plaintiffs' proposed plan).

${ }^{57}$ Id. at app. ser. III. 
posal was relatively modest, resulting in only a small number of African American and white students attending school together. ${ }^{58}$

LDF's plan also addressed the issue of faculty and staff assignments. This part of the plan outlined broad principles, declaring, for instance, that seniority would govern the dismissal or demotion of individuals within any professional class of employment; that those dismissed or demoted should be considered for any other positions available in the district for which they were qualified; and that hiring and promotion would be governed by "reasonable, nondiscriminatory and reviewable standards and procedures." ${ }^{59}$ Moreover, LDF's proposal required that the ratio of black to white employees in professional positions approximate the ratio of black to white teachers in the school system, as mandated by the Fifth Circuit's two-year-old decision in Singleton v. Jackson Municipal Separate School District. ${ }^{60}$ Finally, LDF's plan included a provision requiring the district to submit reports on a biannual basis setting forth data to demonstrate its compliance with the plan's goals regarding student, faculty, and staff desegregation. ${ }^{61}$

Because the Supreme Court (in Swann, Green v. County School Board, $^{62}$ and Alexander v. Holmes County Board of Education ${ }^{63}$ ) and the Fifth Circuit (in Singleton, United States v. Jefferson County Board of Education, ${ }^{64}$ and prior orders in Calhoun itself) had already found each of the elements of LDF's plan constitutional, its proposal was not contro-

${ }^{58}$ See id. at app. (detailing projected results of a plan that would still leave most schools with a black population greater than seventy percent).

${ }^{59} I d$. at app. (Staff Desegregation).

${ }^{60}$ See Singleton v. Jackson Mun. Separate Sch. Dist., 419 F.2d 1211, 1218 (5th Cir. 1969) (requiring for the 1969-1970 school year that the ratio of black to white staff members be substantially the same as that of black to white teachers); see also Singleton v. Jackson Mun. Separate Sch. Dist., 426 F.2d 1364, 1365 n.2 (5th Cir. 1970) (adopting the earlier Singleton faculty-staff assignment ratio as the standard for a unitary system).

${ }^{61}$ Plaintiffs' Proposed Desegregation Plan, supra note 56, at app. (Staff Desegregation); $c f$. Plaintiffs' Proposed Findings of Fact and Conclusions of Law at 9-10, Calhoun (No. 6298) (on file with NARA, case file, box 55, folder 3) (stating that plaintiffs' calculations of the racial composition of Atlanta's schools were based on annual reports submitted by defendants to the federal government, as required by law).

${ }^{62}$ See 391 U.S. 430, 439-41 (1968) (holding that freedom-of-choice plans that did not produce unitary school systems were constitutionally inadequate).

${ }^{63}$ See 396 U.S. 19, 20 (1969) (per curiam) (“[C]ontinued operation of segregated schools under a standard of allowing 'all deliberate speed' for desegregation is no longer constitutionally permissible.... [E]very school district is to terminate dual school systems at once and to operate now and hereafter only unitary schools.").

${ }^{64}$ See 380 F.2d 385, 389-90 (5th Cir. 1967) (per curiam) (holding that school districts have an affirmative duty to desegregate and racial ratios are appropriate rules of thumb for measuring the effectiveness of a school desegregation plan). 
versial as a matter of law. Hence, the response of the board of education to LDF's proposal did not focus on the law as such. Rather, it attacked the scale of the proposal, characterizing it as a "mass busing plan." The board claimed that, in Atlanta, busing students would be impractical, disruptive, and prohibitively expensive because the city did not own any school buses. (This contention was a partial truth, however, since the convention in Atlanta was that thousands of students traveled to school through an arrangement with a private city transit system at reduced fares. ${ }^{6 i 6}$

At the same time as the board vehemently objected to busing, the defendants offered LDF what the board undoubtedly viewed as an olive branch-namely, a school board resolution that affirmed its commitment to increasing the number of African American administrators in the school system. The board promised to "increas[e] the number of Blacks in key positions" by "increasing the number of available key positions." ${ }^{67}$ It further proclaimed: "In order to perfect a better racial balance in key positions now held mainly by Whites, needed new positions will be created for Blacks immediately, and, further, it will be the policy of this Board to fill the places that become vacant with Blacks until the imbalance in this area is corrected." Thus, whereas the board objected to additional expenditures for transporting students to achieve desegregation, it jumped at the opportunity to fund new positions for black professionals. In fact, employing rhetoric more consistent with a separate but equal system than with Brown, the defendants stated that "[i]n each functional responsibility there will be both Black and White schools, faculty and services." ${ }^{69}$

The board's response to LDF's proposal drew a line in the sand. Its strategy pitted two complementary goals-pupil integration and equal employment opportunities for school faculty and administration-against each other. Although both goals were legally mandated, the defendants offered to honor the rights of only one of two subgroups of the African American population. Teachers and administrators could win or students could win-but not both.

05 Defendants' Response to Plaintiffs' Alternate Plan for Further Desegregation at 2-5, Galhoun (No. 6298) (on file with NARA, case file, box 55, folder 3).

\footnotetext{
${ }^{66} I d$. at $4-5$.

id. at 10 .

is $\mathrm{Id}$. at 11 .

69 Id. at 10 .
} 
After hearing evidence from the parties on the propriety of LDF's plan and listening to the defendants' objections, the district court sided with the school board. ${ }^{70}$ Even though they acknowledged the school board's claim that Atlanta owned no buses as an irrelevant consideration under binding precedent, Judges Sidney Smith and Albert Henderson Jr. rejected LDF's plan as "unreasonable." The court's ruling was based on its determination that segregation in the system resulted from "de facto forces completely beyond its control, primarily in terms of housing, population shifts, and the resegregation process." $^{\text {"72 }}$ Rather than considering that the Supreme Court approved the Swann remedies precisely because of the interrelationship of such factors, the court rejected LDF's proposal. Paradoxically, the complex ways in which racial discrimination had been perpetuated in Atlanta over the years proved to be constitutionally advantageous to the perpetrators.

The LDF lawyers were undaunted. A few weeks after the district court issued the order rejecting LDF's desegregation plan and finding the Atlanta school system unitary, LDF made a three-pronged attack in pursuit of its remedial vision. It appealed the district court's June 1972 order to the circuit court; made a motion to consolidate Calhoun with two school desegregation suits pending in Fulton and Dekalb counties (suburban districts surrounding Atlanta) and to amend its complaint by adding certain Georgia state actors, including housing authorities, as defendants; and rebuffed the school board's overture regarding black staff positions. ${ }^{73}$ The first two initiatives were in keeping with LDF's already clear intention to press on in its pursuit of a pupil desegregation decree consistent with Swann. By contrast, the clarity of its statement objecting to the defendants' offer to increase black administrative positions was new and especially poignant. In a July 1972 brief, LDF showed its resolve to attain a remedy "with teeth" for what it alleged was continued faculty and staff segregation in At-

${ }^{70}$ See Calhoun v. Cook, No. 6298 (N.D. Ga. June 8, 1972) (denying plaintiffs' proposed desegregation plan).

${ }^{71} I d$. at $10-11,15-16$.

72 Id. at 11 .

${ }^{73}$ Plaintiffs' Notice of Appeal, Calhoun v, Cook (5th Cir. filed June 23, 1972) (No. 72-2453) (on file with NARA, case file, box 55, folder 2); Brief for Plaintiffs-Appellants, Calhoun v. Cook, 469 F.2d 1067 (5th Cir. 1972) (No. 72-2453) (on file with NAACP Papers, Library of Congress, Wash., D.C. (NAACP Papers), part V, box 682); Supplemental and Amended Complaint, Calhoun (No. 6298) (on file with NARA, case file, box 55 , folder 2 ). 
lanta's school system. ${ }^{74}$ In response to the school board's resolution promising to increase the number of African Americans in "key positions," LDF argued:

Nothing will be rectified by assigning Blacks to new "Black" jobs created especially for them; the proper remedy lies in [e]nsuring Black professional personnel their natural and rightful place in the upper levels of administration in the Atlanta School System. This result will be accomplished, not by broad statements of policy, ... but by the creation of a procedure by which Blacks may first become aware of administrative staff openings, and then compete for such openings on the basis of their professional qualifications and experience in the Atlanta Public School System. $^{75}$

\section{B. Secret Settlement Negotiations Begin}

\section{LDF and the ACLU's Reading of Swann Inspires an Insurgency}

LDF's aggressive litigation stance caused considerable consternation among Atlanta's biracial elite. They found LDF's unwillingness to accept the school board's settlement offer regarding faculty and administrative hiring particularly gauling. As a result, the elites began planning in July 1972 to intercede in the case and bring it to an end.

Other factors were also at work in the elites' escalating concern about the desegregation litigation. On June 8, 1972, the same day that the district court declared that the school board was not responsible for remedying persistent school segregation in Atlanta because it was the result of housing patterns and other circumstances beyond the board's control, Margie Hames, an Atlanta attorney affiliated with the Georgia chapter of the American Civil Liberties Union (ACLU), filed a lawsuit on behalf of twenty-six low-income African Americans (almost all women) that was predicated on precisely the opposite argument. $^{76}$ At its most elemental level, the theory behind Armour v. Nix was that the relationship between school and residential segregation could be proven. ${ }^{77}$ Specifically, Hames set out to prove that a series of

${ }^{74}$ Plaintiffs' Response to Defendants' Staff Desegregation Proposal at 3, Calhoun (No. 6298) (on file with NARA, case file, box 55, folder 2).

Id. at 4.

${ }^{76}$ Armour v. Nix, Civ. No. 16708, 1979 U.S. Dist. LEXIS 9609 (N.D. Ga. Sept. 24, 1979).

See id. at *39-40 ("Plaintiffs have presented the ingenious argument that past segregative acts on the part of school officials contributed to the formation of housing patterns which caused segregation in the schools today."). 
intentional acts by state and local officials and entities, such as school boards, on the one hand, and quasi-public and private officials and entities, such as the Metropolitan Planning Commission and real estate agencies, on the other, had produced Atlanta's pattern of racially identifiable schools and neighborhoods. In light of this conspiracy's scope, the ACLU sought a broad-based remedy-in particular, a pupil desegregation decree fashioned without regard to the reality of white flight from Atlanta's city limits. Hames requested a metropolitan-wide desegregation plan-one in which local school boards across the six regions encompassing the city of Atlanta and the surrounding suburbs would operate jointly, or as a "federation," for purposes of pupil attendance and a limited number of related activities. ${ }^{78}$

This unsettling combination-LDF's uncompromising stance in Calhoun regarding both pupil as well as faculty and administrative integration, and the ACLU's new effort through the Armour lawsuit to create a federated school system-inspired Atlanta's elite biracial decision makers to take action. As a result of these developments, elite whites and blacks renewed settlement discussions, which had first begun in 1971 on the heels of the Fifth Circuit decision that opened the door to Swann-type remedies in Atlanta.

\section{The Insurgent Elite Devises a Plan to Upset the Civil Rights Lawyers' Strategy}

In the style that had been typical of the Atlanta biracial power structure since the post-War era, businessmen and civic leaders held their negotiations about the school desegregation settlement in secret. Those in attendance at the secret sessions included white and black elites who opposed a Swann remedy. The whites included two school board members and Calhoun defendants, Frank Smith and William VanLandingham, also Executive Vice President of the Citizens and Southern Bank. Even more remarkably, the white negotiators included Griffin Bell, a former partner at the premier Atlanta law firm King \& Spalding and a sitting federal appellate court judge; and John Letson, who, as superintendent of the Atlanta school board during the

${ }^{78}$ For discussions of the plaintiffs' proposed plans, see Plaintiffs' Proposed Findings of Fact (filed Oct. 24, 1977), Ammour (Civ. No. 16708) (on file with NAACP Papers, part V, box 659); Gene Guerrero, Atlanta Schools: The Case for Metro Relief, ACLU MAG., Apr. 1975 (on file with Pauley Papers, Emory University Library, Atlanta, Ga. (Pauley Papers), box 29, folder 1); Memorandum from Roger Mills, Attorney, ACLU, to Gene Guerrero, Executive Director, ACLU of Georgia, et al. (Apr. 1975) (on file with Pauley Papers, box 17, folder 5). 
1960s, had encouraged whites to flee Atlanta's public schools. The primary African American negotiators were Lonnie King, president of the Atlanta branch of the NAACP and a former leader of the student movement; Lyndon Wade, Executive Director of the Atlanta Urban League and chairman of the "biracial committee" appointed by the district court in Calhoun; Benjamin Mays, former president of Morehouse College and, as a member and president of the school board, a Calhoun defendant; and finally, Jessie Hill Jr., of the Atlanta Life Insurance Company, who had joined the school desegregation suit as a plaintiff in 1967.

Judge Bell's starring role in the settlement negotiations gave the proposal legitimacy but later proved controversial. Bell orchestrated the discussions by explaining the significance of the Fifth Circuit's June order and other recent precedents at a private meeting of Atlanta's movers and shakers. ${ }^{80}$ In light of these rulings, the judge advised the men that dilatory tactics were no longer legally feasible but that the elite could best the court, and avoid the imposition of metropolitan relief in Atlanta, by moving Calhoun beyond the court's purview. ${ }^{81}$ Bell recommended settling the case, and doing so without the involvement of the attorneys of record-the plaintiffs' lawyers, in par-

${ }^{79}$ Hill was the only black negotiator who was also a party to the case. For more background on the meetings and the participants, see Motion to Reconsider at 1-3, Calhoun (No. 6298) (on file with NARA, case file, box 53, folder 7) [hereinafter Motion to Reconsider]; Cl_ARENCE N. STONE, REgIme POlitics 64 (1989). See also DAVID ANDREW HARMON, BENEATH THE IMAGE OF THE CIVIL RIGHTS MOVEMENT AND RACE REIATIONS 254-56 (1996) (discussing the secret negotiations between white school board members and members of the local NAACP, which advocated a position contrary to the one put forward by national LDF attorneys); Junie Brown, Staffers Join School Talks, ATlanTa J., Nov. 14, 1972, at 2A [hereinafter Brown, Staffers Join School Talks] (reporting that negotiation sessions lasted sixteen hours and Jessie Hill and Lyndon Wade later met with the entire school board); Beau Cutts, City-NAACP Pact: School Compromise Sought, ATLANTA CONST., Nov. 14, 1972; Mike Raffauf, A Tale of Deals: Atlanta Desegregation and the Power Structure, GREAT SPECKLED BIRD, Mar. 19, 1973, at 4 (attacking Lonnie King and the secretly negotiated compromise plan); Minutes of Meeting with Atlanta Branch Officers in New York at 11 (Mar. 6, 1973) (on file with NAACP Papers, box 685). Letson was removed from the settlement talks after his participation was reported in the press. See Junie Brown, Letson Taken out of School Plan Bid, ATLANTA J., Nov. 15, 1972, at 1A (reporting that Dr. John Letson was taken out of negotiations at the NAACP's request).

80 See HARMON, supra note 79, at 254 (noting that Judge Bell was the guest speaker at a meeting of the Atlanta Action Forum, consisting of white and African American business leaders, where he spoke about school desegregation legal precedents and urged members to negotiate an out-of-court settlement).

$I$ Id. 
ticular. ${ }^{82}$ Since Bell's remarks were made out of the public view and only later divulged, his ethics were not questioned at the time, even though he was a sitting Fifth Circuit judge advising a group to settle Calhoun in a manner that impeded the Fifth Circuit's command that Swann-type remedies be considered in Atlanta. (Later, when he was nominated by President Jimmy Carter to be U.S. Attorney General, Bell came under fire from the national NAACP, the ACLU, and the Congressional Black Caucus for his role in the negotiations. Leaders of these groups alleged that his activities, at the very least, represented a potential conflict of interest and probably constituted a serious breach of judicial ethics. These charges did not impede his appointment.) ${ }^{83}$

Neither the plaintiffs' attorneys nor the general public were aware that a settlement was being discussed until the fall of 1972. At that time, the Atlanta Joumal reported that an unidentified but "impeccable" source had divulged that secret negotiations were taking place. ${ }^{84}$ The source explained that those involved in the negotiations-including members of the school board required by Georgia's open meeting (or "sunshine") law to meet in public-would be excluded from further meetings if they divulged information about the talks to anyone outside the circle of self-appointed negotiators. ${ }^{85}$

The negotiators set their sights on defeating the efforts of LDF and ACLU attorneys to bring about a metropolitan-wide school deseg-

${ }^{82} I d$.

${ }^{83}$ Bell's entire record in civil rights cases while on the bench was considered "mixed," at best; in addition, his membership in Atlanta clubs that excluded Jews and Blacks-clubs from which he initially refused to resign-caused outrage in the civil rights community and beyond. For discussions of the negotiation, Bell's actions, and his subsequent career, see Motion for Recusal of Judge Griffin Bell at 1-3, Armour v. Nix, Civ. No. 16708, 1979 U.S. Dist. LEXIS 9609 (N.D. Ga. Sept. 24, 1979) (on file with NARA, case file, box 55, folder 5); HARMON, supra note 79, at 253-55; Ex-U.S. Appeals Judge Is Reported Chosen as Attorney General, N.Y. TIMEs, Dec. 20, 1976, at A1; Thomas A. Johnson, Black Caucus Uneasy over Carter Cabinet, N.Y. TIMES, Dec. 21, 1976, at A25; John P. MacKenzie, Criffin Bell on and off U.S. Bench: A Litigating Lawyer and a Negotiator, WASH. POST, Dec. 23, 1976, at A18.

${ }^{84}$ Cutts, supra note 79.

${ }^{85}$ Id.; see also Brown, Staffers Join School Talks, supra note 79 ("[Board members] were told if they talked to news reporters they would be excluded from further negotiations."). For Georgia's "sunshine" laws-requiring certain government meetings to be open to the public-in effect during the negotiation period, see GA. CODE ANN. $\$$ 23-802 (1966); 1972 Ga. Laws 575. See also McLarty v. Board of Regents, 200 S.E.2d 117 (Ga. 1973) (noting that the purpose of Georgia's Open Meetings Act was to eliminate "closed meetings which engender in the people a distrust of its officials who are clothed with the power to act in their name"). 
regation plan. An October 6, 1972, ruling by the Fifth Circuit ensured that the negotiators' objective would be no simple task. ${ }^{86}$ In its October ruling, the Fifth Circuit again reversed the district court's declaration that the Atlanta school system was unitary. Furthermore, the court ordered the implementation of a desegregation plan in which the "fear of white flight" was not "utilized as a factor" in design, segregated schools were paired or grouped in accordance with Swann, and transportation was provided to students as needed. ${ }^{87}$

Another ruling, issued during this time by Judge Griffin Bell, was equally significant. Bell became formally and publicly involved in Calhoun in the weeks after the Fifth Circuit reversed the district court's finding of unitariness in his capacity as a member of a three-judge panel presiding over that part of Calhoun (regarding metropolitanwide relief) that had been consolidated with the ACLU's Armour suit. On November 17, 1972, Bell and his colleagues issued an order staying the proceedings in Armour on the theory that cases involving metropolitan relief pending in other circuit courts might impact a judge's opinion regarding the advisability of metropolitan relief in Atlanta. ${ }^{88}$ Bell's reasoning regarding the propriety of granting a stay was reasonable on its face. However, the immediate impact of the stay was to buy time for those wishing to resolve Calhoun in a manner that removed Swann-type remedies from consideration. Once Calhoun was settled absent a consideration of metropolitan relief, the practical effect would be to prevent the Atlanta school system-the only one of the six districts involved in Armour that included a majority black population-from being a part of the federated school system proposed by the ACLU. ${ }^{89}$

${ }^{86}$ Calhoun v. Cook, No. $72-2453$ (5th Cir. Oct. 6, 1972) (on file with NARA, case file, box 55 , folder 1$)$.

${ }^{87}$ See id. at 1-3 (ordering the Atlanta public school system to proceed with desegregation, outlining guidelines and conditions, and recognizing that success would be dependent on both sides' full cooperation with the spirit and letter of the court's order).

Armour v. Nix, No. 16708, at 1-3 (N.D. Ga. Nov. 17, 1972) (on file with NARA, case file, box 55, folder 1). The cases involving metropolitan relief arose in Detroit, Richmond, and Denver.

${ }^{89}$ Margie Hames argued that the stay was improper and should be lifted. Brief in Support of Motion to Vacate Stay at 1-5, Armour (No. 16708) (on file with NARA, case file, box 55 , folder 1 ). 


\section{LDF Is Expelled from Its Own Case}

With the stay in place, the negotiators turned to the singularly most important and spectacular of the series of events that resulted in the settlement of the school desegregation case: LDF was expelled from its own case. Lonnie King, president of the Atlanta NAACP chapter, engineered the removal of LDF attorney James Nabrit III from the Calhoun litigation. In November of 1972-after the U.S. Supreme Court refused to stay the Fifth Circuit's order to the school district to implement a comprehensive desegregation plan ${ }^{90}$ and Nabrit denounced the ongoing settlement talks' exclusion of LDF-King maneuvered his way into the litigation and froze Nabrit out.

King did so by obtaining powers of attorney from eight of the twenty-eight original Calhoun plaintiffs. Then, acting as these plaintiffs' legal representative, King fired Nabrit and hired attorney Benjamin Spaulding - a novice in comparison to Nabrit-to replace LDF attorneys as plaintiffs' counsel. King claimed that Nabrit was fired after consultation with the plaintiffs, who enthusiastically supported LDF's removal. With that, LDF was ousted from its own case, deposed by a man whose role as chief decision maker for the plaintiffs was selfappointed and whose putative constituency was, at best, unrepresentative of the plaintiff class as a whole and, at worst, nonexistent. ${ }^{91}$

King's ability to exercise such a powerful influence over the case can be traced to the decades-long demise of the Atlanta branch of the NAACP. The branch had fewer than 2000 members in 1966, despite a wide-ranging campaign to increase its membership to a respectable level after it dropped to a record low of twenty-four in 1964, according to one report. The Atlanta NAACP was considered virtually defunct

\footnotetext{
${ }^{90}$ See Cook v. Calhoun, 409 U.S. 974, 974 (1972) (denying the application for a stay).

${ }^{91}$ Interview with Elizabeth Rindskopf Parker, Counsel, LDF, 1971-1974, in Madison, Wis. (Sept. 9, 2000); see Calhoun v. Cook, 469 F.2d 1067, 1067-68 (5th Cir. 1972) (per curiam) (listing Benjamin Spaulding as an attorney for the plaintiffs-appellants); Junie Brown, School Negotiation Could Be Periled, ATLANTA J., Nov. 10, 1972, at 1A (reporting a "split ... between the Atlanta leaders of the [NAACP] and its legal counsel, [LDF]," and that the split could "jeopardize attempts to settle the Atlanta school desegregation case out of court"); Junie Brown, School Plan Accord Seen, ATLANTA J., Nov. 20, 1972, at 2A (describing a split between Nabrit and local NAACP officials and King's hiring of Benjamin Spaulding to handle the case); Memorandum from Mercedes Wright to Nathaniel Jones (Nov. 16, 1972) (on file with NAACP Papers, part V, box 682) (informing Jones that the Executive Committee of the Atlanta NAACP branch voted to dismiss James Nabrit as attorney of record); Memorandum from Atlanta Branch NAACP to Ruby Hurley, Director, S.E. Region NAACP (n.d.) (on file with NAACP Papers, box 684) (detailing the events leading to LDF's dismissal).
} 
by national NAACP officials, who thought a city of Atlanta's size should produce 10,000 to 15,000 members. King had secured the branch presidency in 1968 without formal opposition and despite procedural irregularities, including voting by inactive or unqualified members. Indeed, the branch's recordkeeping was so shoddy that it was impossible to determine with certainty whether voters were members in good standing. ${ }^{92}$ Nevertheless, the NAACP's name and cachet suggested that King, as chapter president, represented a broad and active constituency. In reality, King represented himself and the few other black elites, such as Lyndon Wade, Benjamin Mays, and Jessie Hill Jr., who wanted a swift settlement of the school desegregation litigation-not the Calhoun plaintiff class as a whole. King insinuated himself into the litigation as the voice of black Atlanta over the objections of the Armour plaintiffs, LDF, the national NAACP, and the Congress of Racial Equality (CORE). As we shall see below, these objections were based on evidence that King had committed serious improprieties-misdeeds that made him unfit to represent the plaintiff class.

\section{The Court Considers the Class's Due Process Rights, and LDF Falters for the Sake of Racial Unity}

King could not have accomplished his feat without the court's approval and, as it turns out, without LDF and ACLU attorneys, who made tactical blunders in responding to King's power grab. The drama of King's move to depose LDF as lead plaintiffs' counsel first played out in court in December of 1972. The issue came before the Fifth Circuit when King, with Spaulding as his attorney, filed a motion requesting the removal of $L D F$ as counsel of record and the substitu-

${ }^{92}$ On the size of the membership and the national NAACP's projected figures, see Letter from Gloster B. Current, Director of Branches and Field Administration, NAACP, to Joe Louis Tucker, Georgia Field Director, NAACP (May 2, 1966) (on file with NAACP Papers, part IV, C6, 1966-1969 file); Letter from Albert R. Sampson, Executive Secretary, Atlanta Branch NAACP, to Gloster B. Current (Aug. 17, 1964) (on file with NAACP Papers, C27, 1964-1965 file). On procedural irregularities in the election of NAACP officials in 1968, see Letter from Gloster B. Current to Honorable Donald G. Hollowell (Nov. 19, 1968) (on file with NAACP Papers, part IV, C6, 19681969 file); Letter from Donald G. Hollowell, Executive Director, EEOC, Atlanta Region, to Gloster Current (Nov. 23, 1968) (on file with NAACP Papers, part IV, C6, 1968-1969 file).

${ }^{93}$ Interview with Elizabeth Rindskopf Parker, supra note 91; see also Raffauf, supra note 79 , at 2 (stating that King split with LDF and the national NAACP by backing a compromise settlement that was contrary to the court order and was essentially "selling-out"). 
tion of Spaulding. Rather than acceding to that extraordinary request, the Fifth Circuit issued an order remanding the motion to the district court for a hearing. ${ }^{94}$ The district court convened the hearing on December 28, 1972. It was attended by Howard Moore and Elizabeth Rindskopf, who represented LDF; Spaulding, in his capacity as attorney for King and eight of the Calhoun plaintiffs; and Margie Hames, counsel for the Armour plaintiffs. ${ }^{95}$ The purpose of the hearing was to determine which attorneys legitimately represented the Calhoun plain tiff class. ${ }^{96}$

To the apparent astonishment of the district court, Moore and Spaulding played the roles of amicable co-counsel rather than antagonists during the hearing. The rash of stories that had recently appeared in the press regarding fissures within the Calhoun class, ${ }^{97}$ as well as Moore's public statements a month earlier describing blacks who negotiated with the school board as "Uncle Toms" and the exchange of pupil desegregation for administrative jobs as tantamount to a "slave auction," made the coziness between the two especially perplexing. Nevertheless, during the hearing Moore and Spaulding jointly refused to address questions propounded from the bench regarding the significance of Spaulding's entry into the case as counsel for part, rather than all, of the plaintiff class. When Judge Smith implied that Spaulding could not be a legitimate representative of the entire class because it consisted of the approximately 50,000 African American children in the school system, rather than only the eight from whom King had attained powers of attorney, Moore insisted that these facts presented "no controversy about... the make up of the

${ }^{94}$ Calhoun, 469 F.2d at 1068.

${ }^{95}$ See Record of Dec. 28, 1972 at 5, 6, 13, 27, Calhoun v. Cook, No. 72-2453 (N.D. Ga. 1972) (on file with NAACP Papers, part V, box 684) (recording their comments).

${ }^{96}$ See Calhoun, 469 F.2d at 1068 (remanding "to the district court with directions to ... [h]old such hearings as may be required to enable the Court to determine the present status of the class or classes in this litigation and the status of legal representation"); Record of Dec. 28, 1972, supra note 95, at 2-3 (quoting dialogue between Judge Smith and the defendants' counsel regarding the purpose of the hearing).

97 See Record of Dec. 28, 1972, supra note 95, at 10 (recording Judge Henderson's comments about the press reports that indicated the lack of harmony in the Fifth Circuit proceedings).

${ }^{8}$ See Junie Brown, Surprise Lauyer Raps Atlanta Plan in Court: Argument Splinters Blacks' School Case, ATLANTA J., Nov. 22, 1972, at 1A (reporting that Moore lambasted a compromise desegregation plan drafted by school officials and the local NAACP as one drawn by the white establishment and a group of "Uncle Toms").

${ }^{99}$ See Steve Stewart, Court May Draw Own Atlanta Schools Plan, ATLANTA J., Nov. 23, 1972, at 1A (noting that Moore called King's compromise plan "a slave auctioning himself more or less"). 
class, or the relief and scope of the relief which the class seeks." Spaulding no longer wished to substitute counsel, Moore stated, and had withdrawn the motion; LDF had agreed to add Spaulding as counsel in the action. ${ }^{101}$

The court refused to so readily dismiss the Fifth Circuit's concerns about the plaintiffs' representation, despite Moore and Spaulding's agreement. Demonstrating concern that proper procedures be followed "where some question may arise as to who represents the class," Judge Henderson indicated that the members of the class nevertheless should be notified about developments in the case and perhaps even be allowed to "bring their own lawyer in" to protect their interests. ${ }^{102}$ Moore strenuously objected to these suggestions, arguing that no circumstance had arisen that required notice to the class members. "That is not ... [the] question," Moore said, because "there is no dissension" as to "who counsel are in this case representing the class."

With Moore continuing to argue that he and Spaulding were authorized to speak for all of the plaintiffs in the case and that there was no need to provide clients with a forum to voice their views of the adequacy of their representation, Judges Smith and Henderson began increasingly to focus on the question of whether LDF attorneys were dominating the case to the exclusion of their clients. Smith commented that " $[\mathrm{t}]$ hese school suits . . . are the only cases really run by the lawyers and not by the class," noting that the judges had not "even seen a member of the class" because " $[t]$ hey haven't been in the courtroom, they haven't testified as witnesses or anything." Henderson agreed, arguing that the plaintiffs' lawyers, whether Moore or Spaulding, were in the "[m] ost envious position in the world." ${ }^{105}$ He continued:

I don't know of another lawyer in the whole country that can control litigation like [it has been] controlled in this case... . I think we would all have to recognize, to be perfectly honest, that this has always been litigation controlled by the lawyers and not by the class itself. ${ }^{106}$

The issue was moot, Moore and Spaulding repeated again and again, because the lawyers had worked out the initial problem among them-

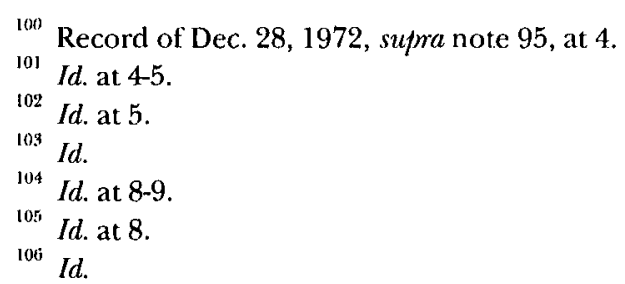


selves, thereby negating the need for the plaintiffs to become involved in the litigation. In the end, Moore and Spaulding carried the day: the court accepted the contention that there was no need to further pursue the question of whether the plaintiffs were properly and adequately represented or to hear from any plaintiff class members on the subject. $^{107}$

Moore's surprising stance was planned, an outgrowth of the national NAACP's and LDF's desire to avoid the embarrassment of a prolonged public fight with the Atlanta branch. King and Spaulding had agreed to present a united front in court, hoping that they could convince the national groups to allow the branch to pursue a negotiated settlement of the case and perhaps even to join in the negotiations. Still, the strategy was not without controversy. Despite her private concerns, Rindskopf, the junior attorney on the case, had been in no position publicly to disagree with Moore's strategy and thus spent most of the hearing in silence. Hames failed to challenge the unlikely alliance between LDF and Spaulding because of a promise of sorts from Judge Griffin Bell that, however Calhoun was resolved, it would not affect Hames's suit for metropolitan relief. Even so, Hames-unlike Moore-did inform the court that she did not and could not waive the rights of her clients to challenge Moore's or Spaulding's representation in the future. ${ }^{108}$ That caveat was not enough, however, to guarantee that her clients' rights would be preserved, as became clear a few months later. ${ }^{109}$

As I describe more fully below in the analysis of the so-called "compromise" settlement, LDF and ACLU attorneys squandered an important opportunity at the December 1972 hearing on the adequacy of plaintiffs' representation. They blundered by acquiescing to Spaulding's appearance in the case and by failing to impress upon the court the vast differences between their remedial approaches and those of the King-led faction represented by Spaulding. By March, a King-brokered settlement agreement with the school board had gained momentum, particularly among the white, antibusing public and in the white-owned media. By this time, LDF attorneys, who con-

${ }^{107}$ See id. at 2-14 (recording the discussion between the judges and Moore and Spaulding).

${ }^{108}$ Interview with Elizabeth Rindskopf Parker, supra note 91; see also Record of Dec. 28, 1972, supra note 95, at 5-14 ("I could not waive that right [to object to representation by Moore, Spaulding, and Rindskopf] on behalf of the parties I represent.").

109 See infra text accompanying notes 119-25 (discussing Hames's later objection to Spaulding's representation and Judge Smith's rejection of her arguments). 
tinued to insist on a remedy consistent with Swann, were being publicly excoriated by Lonnie King as "damn Yankees" who had invaded Atlanta like Sherman, this time by running roughshod over the priorities of Atlanta's black community. ${ }^{110}$ Had LDF and Hames pushed ahead with their objections in December, when Judges Smith and Henderson were amenable to the argument that King and Spaulding's entry into the case was improper, it is likely that the settlement never would have been considered by the court, or if considered, their protests would have been more credible. Having made the calculated decision not to challenge King and Spaulding's entry into the case, the LDF attorneys and Hames later would be in the position of trying to stop a runaway train: a "compromise" settlement that had been under consideration for months.

The "compromise" settlement offered much for African American administrators but less for African American students. Although Brown and its progeny, including Swann, were concerned primarily with dismantling the system of separate but equal schools for children, the Atlanta settlement agreement addressed the needs of school administrators first and foremost. In fact, the first three pages of the twenty-five-page document consisted of a list of thirty-seven administrative positions, seventeen newly created." Pursuant to the settlement agreement, twenty-five of these positions, including sixteen of the new jobs, were to be filled by blacks. The deal stipulated that the superintendent of the school system and the assistant superintendents for community affairs and personnel were to be African American, while the associate superintendent for administration and the assistant superintendent for plant planning were to be white. Three of the area superintendents were to be black, and two were to be white. In addition, blacks were to occupy the new positions of food service coordinator, coordinator of vocational personnel, and deputy director of educational broadcasting, while whites were to have three of the five assistant area superintendent positions and the coordinator of majority-to-minority transfers position. Still, the plan stipulated that its configuration of administrative positions was to be maintained for only three years; thereafter it was not binding. Furthermore, the

${ }^{110}$ See Junie Brown, Clipping, AtLAnTa J.-CONST., § A (n.d.) (on file with NAACP Papers, part IV, box 682) ("We don't appreciate a New York yankee coming down here and telling us how to run our school case ....").

"11 Plan of Proposed Settlement as Devised and Agreed upon Between Plaintiffs and Defendants at 46, Calhoun (No. 6298) (on file with NARA, case file, box 55A, folder 5) [hereinafter Plan of Proposed Settlement]. 
plan's commitment to nondiscrimination and racial balance regarding staff (defined as teachers and principals) was unclear. It included many provisions that would exempt officials from complying with Fifth Circuit precedent requiring that the ratio of black to white teachers in a school reflect that of the overall student population in the school system. ${ }^{112}$

While the settlement proposal could not have been more explicit in establishing a racial balance system for administrative positions, the deal makers eschewed the principles espoused in Swann regarding pupil desegregation. The proposal did not take advantage of the remedial tools approved by the Swann Court to desegregate pupils, such as assigning and transporting students to schools not contiguous to their neighborhoods in order to make the schools more racially balanced. Instead, the proposal seemed designed to minimize rather than maximize interracial contact among students. Professor Michael Stolee, an expert retained by the plaintiffs, argued that the agreement minimized pupil desegregation to such an extent that eighty-three of the city's 153 schools, with 59,064 students (a majority of the system's pupils), were left ninety percent or more black. ${ }^{113}$ That is, they were not desegregated at all under the Fifth Circuit's indulgent standards, pursuant to which a school with an eighty-nine percent black population was considered desegregated. Among the eighty-three schools that were to remain segregated, forty-five schools, containing 32,817 students, had one hundred percent black enrollment. Only 814 white students and 1951 African American students were to be bused under the plan. Moreover, to the extent that any busing occurred at all, it would be the children of working-class and poor black families (and a few whites) who would bear the brunt of the transportation burdens. Middle- and upper-income black neighborhoods were unaffected by busing, while children from poor communities, such as northwest Atlanta's Archer School community, were subject to busing under the plan. At the same time as it eschewed racial balance mandates for pupils, the plan endorsed the voluntary student transfer program, even though the Supreme Court had rejected such freedom-of-choice programs as effective remedies for de jure segregation in its 1968 decision

\footnotetext{
${ }^{112} I d$. at 3-9; see also supra note 60 and accompanying text (referencing Fifth Circuit precedent on the issue).

${ }_{13}$ Affidavit of Michael J. Stolee at 1-15, Calhoun (No, 6298) (on file with NARA, case file, box 55A, folder 3) [hereinafter Stolee Affidavit].
} 
Green v. County School Board, ${ }^{114}$ and again in 1969 in Alexander v. Holmes County Board of Education. ${ }^{115}$

D. Civil Rights Lawyers and Their Client-Communities React to the Settlement

\section{An Unconstitutional Settlement?}

The compromise negotiated by Lonnie King was a plan containing provisions that the Fifth Circuit twice had rejected as constitutionally inadequate in the previous year. LDF attorneys Moore and Rindskopf refused to sign the agreement and, along with Margie Hames, filed objections to the settlement in the weeks after February 23 when the plan was submitted to the district court. In a March 8 filing, the LDF attorneys repudiated their position at the December hearing, where they had downplayed their disagreements with Spaulding and King. Moore and Rindskopf now importuned the court to reject the settlement because Spaulding and King's objectives were incompatible with theirs. They argued that the pair's negotiation of the settlement and their attempt to have it approved by the court (notwithstanding the fact that many members of the class did not agree with it) violated the Due Process Clause. The right of African American students to attend a desegregated school could not be waived by class representatives, Moore and Rindskopf argued, particularly when their attorneys objected to the waiver. ${ }^{116}$

Regarding the substance of the plan, Moore and Rindskopf argued that the pupil assignment scheme endorsed by Spaulding and King violated the Equal Protection Clause because it left Atlanta's segregated school system substantially intact. Moreover, while claiming that extensive school transportation of both African American and

114391 U.S. $430,441-42$ (1968).

${ }^{115} 396$ U.S. 19, 20 (1969) (per curiam); see Plan of Proposed Settlement, supra note 111, at $9-15$ (describing the majority-to-minority pupil-transfer plan whereby students could request transfers to schools of their choice if the transfers would further the desegregation of the school system); Stolee Affidavit, supra note 113, at 6 (projecting that, even if all the 705 black children expected to elect the majority-to-minority transfer plan did so, the plan would only provide a desegregated education for $1.2 \%$ of the black children in the eighty-three schools); see also RESEARCH ATLANTA, ANALYSIS of ATlanta COMPROMISE SCHOOL DESEgREgation PlaN 5 (1973) (on file with NAACP Papers, part V, box 683) (analyzing how the compromise plan would expand the scope of the majority-to-minority program).

${ }^{116}$ Cf. Plan of Proposed Settlement, supra note 111, at 9-25 (summarizing the majority-to-minority pupil-transfer plan proposed as part of the settlement, under which students could voluntarily choose reassignment to a desegregated school). 
white students, about 23,000 students total, was needed to achieve a school system considered desegregated under the relevant legal standard, Moore and Rindskopf also argued that the plan violated the Equal Protection Clause because the principal inconvenience of transfers and transportation fell upon poor blacks and, to a lesser extent, low-income white students. The LDF attorneys further objected that the plan to desegregate the staff did not fully comply with Fifth Circuit precedent. They claimed its provisions regarding administrative positions were inadequate because the three-year duration of the commitment to increased black participation in the school administration was too short and, in any event, the plan would not result in meaningful black participation in the administration of the school system. Margie Hames endorsed LDF's objections and later would make several more of her own. ${ }^{117}$

At a hearing on March 8, the same day that LDF filed its written objections to the settlement, Moore and Rindskopf-together with Hames and other interested parties-articulated to the district court their concerns about the King-endorsed plan and Spaulding's and King's roles as representatives of the plaintiffs. Moore and Rindskopf repudiated the position that LDF had taken before the very same judges on December 28; now that their attempts to negotiate with Spaulding and King had ended in failure, the two LDF attorneys, along with Hames, objected to various aspects of the plan, calling them inconsistent with the constitutional requirements set forth in Singleton and Swann.

The judges were disturbed by the attorneys' about-face. In response to Moore's request for an evidentiary hearing regarding the "adequacy of representation of counsel who negotiated" the settle-

117 See Objection to "Plan of Proposed Settlement" Filed Herein and Motion for Order in Accordance with Mandate of Court of Appeals at 1-11, Calhoun (No. 6298) (on file with NARA, case file, box 55A, folder 4) (laying out arguments regarding why the proposed settlement should not be approved by the court); Supplemental Objections to Compromise Settlement, Mar. 29, 1973 at 1-4, Calhoun (No. 6298) (on file with NARA, case file, box 55A, folder 1) [hereinafter Supplemental Objections] (adding two more objections to the proposed settlement); see also Stolee Affidavit, supra note 113, at 1-15 (discussing the proposed settlement and its flaws with respect to the desegregation policy). For additional contemporary sources engaging the debate over the benefits and drawbacks of the various plans, see Junie Brown, OK by Court Doubted for School Plan Here: Integration Measure Includes Little Busing, ATLANTA J., Nov. 17, 1972, at 1A; Junie Brown, School Board, NAACP Agree on Compromise, ATLANTA J., Nov. 21, 1972, at 1A; Donna Lorenz, Desegregation Expert Gripes About City Compromise Plan, Clipping (n.d.) (on file with NAACP Papers, part V, box 684); Susanna McBee, Atlanta Blacks Trade Busing for Power, WASH. POST, Mar. 4, 1973, at A2; Reginald Stuart, Atlanta Splits on School Plan, RACE ReL. ReP., Feb. 19, 1973, at 5, 6-7. 
ment, Judge Henderson expressed that "it is getting extremely frustrating ... that we seem to get these things resolved and we come back today and nobody is in agreement about anything, not even who represents the plaintiffs in the case."118 Similarly, when Hames objected to the plan on the grounds that it had "been written behind closed doors," a circumstance that she said caused it to have an "odor of suspicion," ${ }^{\text {"1!? }}$ Judge Smith reprimanded her for making an issue of Spaulding's representation when she had failed to object to it not three months earlier. ${ }^{120}$

Undaunted, Hames turned the court's focus from her earlier misstep to the traditional requirements in cases of the type before the court; she reminded the court that it was customary to give affected parties notice and a hearing prior to approving a settlement of a class action. ${ }^{121}$ In response to Hames's suggestion, the court took a position that seemed contradictory but that, in fact, revealed the limited extent to which it was willing to consider the possibility that some class members might have interests distinct from those that Spaulding offered to the court. Judge Smith agreed that the court might need to "poll the class to help us form an opinion about whether it is to the best interest of the class to accept the settlement," ${ }^{122}$ but at the same time questioned whether the class members had a "legal right to voice objections." ${ }^{123}$ Moreover, the judge rejected Hames's argument that precedent concerning stockholders' derivative class actions, which stipulated that plaintiffs are entitled to notice and a hearing on the merits of a settlement prior to its approval by a court, were applicable in civil rights actions. ${ }^{124} \mathrm{He}$ concluded that such precedent was inapplicable because the stockholder actions involved "money," never mind Hames's argument that the constitutional rights involved in $\mathrm{Cal}$ houn were "greater than money."

Whereas Hames argued forcefully and passionately to preserve her clients' rights, Moore employed a more restrained and technical approach throughout the hearing. His approach turned on convincing

${ }^{118}$ Record of Mar. 8, 1973 at 32-33, Calhoun (No. 6298) (on file with NAACP Papers, box 685).

${ }^{119}$ Id. at 16 .

${ }^{120}$ Id. at $15-16$.

${ }^{121}$ Id. at 26.

${ }^{122}$ Id. at 27.

${ }^{123}$ Id. at 28.

${ }^{124}$ Id. at $28-29$.

${ }^{125}$ Id. at 28; Interview with Elizabeth Rindskopf Parker, supra note 91. 
the court through written materials, including briefs and affidavits from experts, that the settlement plan was unconsticutional. Moore did not attempt to buttress or match Hames's oratory. For instance, in the face of Judge Smith's suggestion that only those with money at stake were entitled to a hearing prior to a court's approval of a settlement, Moore remained silent, except for his promise to cite authority on the issue in his next legal brief. ${ }^{126}$ Such coyness seems a peculiar strategic choice for Moore, a lawyer who by all accounts was a great talent and unafraid to hurl rhetorical flourishes at an opponent. After all, Moore had harshly criticized Spaulding and King outside of court in the days and weeks leading up to the hearing. ${ }^{127}$

\section{The ACLU Puts a Poor and Human Face on the Legal Proceedings}

Hames sought to put a human face on the proceedings-to explain the settlement's inadequacy in human, rather than strictly legal, terms. To achieve this objective, Hames brought some of her clients to court and encouraged them to speak on their own behalf. The spokesperson for the group of Armour plaintiffs was Ethel Mae Mathews, a leader of the local chapter of the National Welfare Rights Organization, a grassroots advocacy group for recipients of public assistance. Mathews, a welfare recipient living in public housing, had come to the conclusion that poor people had "just as many rights as the rich person." ${ }^{28}$ Moreover, because she had learned from her experiences in the welfare system that abusive caseworkers were just as likely to be African American as white, Mathews was not reluctant to point out the transgressions of persons with authority, even if doing so breached racial solidarity. Mathews strode to the podium and offered her frank opinions after Judges Smith and Henderson asked whether any onlookers had anything to add, and, given her background, this was not surprising.

Unintimidated by her surroundings in the federal district court and undeterred by the way her nonstandard English and lowly status were sure to be viewed by the professionals and civil servants occupying the court room, Mathews unflinchingly proclaimed that the set-

${ }^{126}$ See Record of Mar. 8, 1973, supra note 118, at 66 (capturing Moore's promise to submit appropriate authorities on the question of whether an evidentiary hearing would be necessary if the court were to adopt the proposed settlement).

${ }^{127}$ Interview with Elizabeth Rindskopf Parker, supra note 91 ; see also supra notes 9899 and accompanying text (recounting Moore's appellation of the settlement negotiators as "Uncle Toms" engaged in a "slave auction").

${ }^{128}$ Interview with Ethel Mae Mathews in Atlanta, Ga. (July 6, 2000). 
tlement was illegitimate. Her primary point was that the settlement was the product of a corrupt process. The process was unjust, Mathews said, because people like the Armour plaintiffs, "black peoples and poor peoples," as she described them, had been excluded from the negotiating sessions, "from wheeling and dealing." ${ }^{129}$ According to Mathews, the interests of these "black peoples and poor peoples" had been overlooked by leaders purporting to represent Atlanta's black community, despite the fact that the black poor had suffered most under the unequal system of education. She said:

I am not pleased with the settlement because we black and poor have been sold out for too long, just keep being sold out by our own peoples; so I would like for the Court to [reconsider] and let us poor people be in on the decision as black and poor peoples, because we are the ones can tell, we are the ones that live it, we are the ones that our children go to the ghetto schools. ${ }^{130}$

Mathews went on to express support for a remedy that included busing, but she argued that the busing should be a "two-way street" so that wealthy white children, as well as poor black children, would bear the transportation burden. ${ }^{191}$

Similarly, Edward Moody, a Calhoun plaintiff, forcefully made the point that he saw "buses running everyday," taking students to and from school, and that "nobody questions that busing," yet people were up in arms about the possibility that a desegregation plan would mandate a significant amount of busing. ${ }^{192}$ Joseph Boone, an African American minister who had protested outside of the closed-door settlement negotiations in November of 1972, also demanded "reciprocal" busing and voiced support for the metropolitan relief sought in the Armour suit. ${ }^{133}$ Another minister, Reverend Bernard Lee, chief of staff of the Southern Christian Leadership Conference, adopted a tone like Mathews's in decrying the settlement. He saw deliberate malfeasance: the plan was "designed to set back" race relations in Atlanta "for the next one hundred years," he said, and was yet another attempt to "block school desegregation" in the city, though it was sorely needed, especially for working-class and poor blacks. ${ }^{194}$

\footnotetext{
${ }^{129}$ Record of Mar. 8, 1973, supra note 118, at 35-36.

190 Id.; see also Interview with Ethel Mae Mathews, supra note 128; Interview with Reverend Austin Thomas Ford in Atlanta, Ga. (July 5, 2000).

${ }_{182}^{131}$ Record of Mar. 8, 1973, supra note 118, at 35-36.

${ }^{132}$ Id. at 42.

${ }^{133} I d$. at 61 .

${ }^{134}$ Id. at 61-63.
} 
Remarks by two white defendants, school board members who opposed the settlement, lent support to such sentiments. Mrs. Leroy Woodward buttressed the contention that those who conceived of the plan played favorites when she remarked that the student assignment and transportation plan "was determined by excluding those schools who brought tremendous pressure on the school board and the plaintiffs," resulting in "discrimination toward certain schools." 135 "I am disturbed and concerned that our schools are being used to satisfy personal and political gains," Woodward added. ${ }^{136}$ Likewise, Howard Klein, a school board member, objected to the plan because it was unfair to "poor black" schools.

In addition to these outspoken dissenters, the court heard from two African American laypersons who expressed support for the settlement plan at the March 8 hearing. One of them, Carolyn Crowder, was president-elect of the Fulton High School Parent Teacher Association; she clearly expressed her willingness to defer to the judgment of black leaders such as King. ${ }^{138}$ To distinguish herself from Mathews and others, Crowder declared, "I'm not one of these people that feel I have to be included [in the negotiations]." 139 Her loyalty was to Fulton High, which she wanted to see improved so that black children would not need to be bused to wealthy white neighborhoods to obtain a quality education. ${ }^{140}$ Similarly, the other unambiguous supporter of the settlement, Edith Hammond, identified herself as being "from" (and, implicitly, representing) North Fulton High School, although she did not make clear whether she was attending the hearing in an official capacity. ${ }^{141}$ The words that Hammond used to express her support for the settlement echoed the concerns of many elites about Atlanta's national reputation. By embracing the settlement, she said, the black and white people of Atlanta accepted a "unique opportunity" to "show the country how we can work together" to achieve a "compromise" that had been negotiated in "good faith."

${ }^{135}$ Id. at 49.

136 Id. at $50-51$.

137 Id. at 51.

${ }^{138}$ See id. at 37 ("I do feel that the two parties worked very diligently and very hard and some long, honest hours in trying to come up with a plan that was suitable to most of us.").

\footnotetext{
${ }^{139}$ Id. at 37 .

${ }^{140} I d$.

${ }^{141}$ Id. at 45 .

${ }^{142} I d$.
} 
On March 29, the court convened another hearing, but this one was held for the precise purpose of considering objections to the proposed settlement plan by members of the plaintiff class. ${ }^{143}$ Whereas the March 8 hearing had not been officially announced, a notice printed in local newspapers two weeks prior to the March 29 hearing alerted members of the class, at least those likely to read a daily, of their opportunity to appear and state their objections to the settlement. ${ }^{144}$ Thirty-six individuals testified before the court on March $29 .^{145}$

Several speakers who objected to the settlement expressed strong support for the metropolitan remedy sought in the Armour suit. Many of them dismissed the notion advanced by Lonnie King and the elite backers of the proposed settlement that black parents were opposed to busing. For instance, Mamie Dixon asserted that the issue of how far students had to travel to school had been overblown; she stated unequivocally that "the Metro suit is the answer" to the problem of black schools' inadequacy. ${ }^{146}$ Ethel Mae Mathews, who had spoken so eloquently at the March 8 hearing, again stated her opinion that the King-backed settlement was unjust because it would not enhance the ability of most children in the school system to receive a better education. Flatly stating that the settlement amounted to "our child[ren] be [ing] pawned for a few greenbacks," American parents were not opposed to busing across district lines if doing so allowed their children to attend better schools. ${ }^{148}$ Similarly, Emma Armour, the named plaintiff in Armour, remarked in objecting to the settlement that her children "don't mind bussing" if they could "get the same equal rights as the white children do." ${ }^{149}$ Stanley Wise expressed support for a cross-district remedy because he viewed it as the only way to ensure that the resources routinely available in the white schools were made available to blacks. ${ }^{150}$ Others who objected to the settlement echoed the sentiments of Amour plaintiffs who believed that the poor gained few, if any, benefits from the settlement.

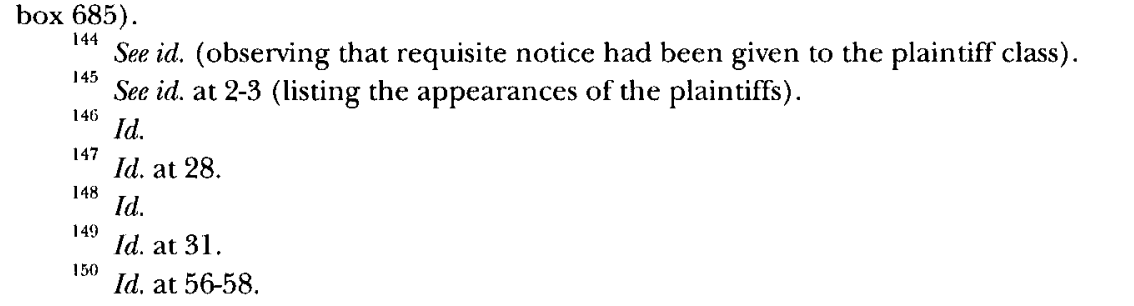


Though Walker Moore did not articulate direct support for the metropolitan remedy favored by the Armour plaintiffs, he objected to the King plan on the ground that only the "poor black people" and the "poor white people" would be "moved about and juggled about" under the proposed settlement. ${ }^{151}$

\section{The Settlement's Supporters Speak}

Even though the hearing was conceived as a forum for plaintiffs who objected to the plan to articulate their points of view, several African Americans testified in favor of the settlement on March 29. Many of those in this camp were obviously dispatched to undercut the impact of those opposing the King plan. In fact, many of these speakers were not even plaintiffs and therefore should not have been heard by the court. For example, Charles Hart identified himself as a member of the Community Relations Commission of the City of Atlanta and read a resolution that he said was passed by its African American and white members on February 27. The resolution admitted the members' displeasure with Calhoun and those responsible for its filing:

The Community Relations Commission wishes to express its appreciation of the Atlanta Board of Education, the Atlanta Chapter of the NAACP and the Biracial Committee for the agreement reached in settlement of the court case which has hung over our schools and our city like a threatening cloud for fifteen years. We are grateful that this settlement has come out of mutual concern to the citizens of Atlanta themselves and has not been imposed by an outside authority or by the Court. ${ }^{152}$

The reference to an "outside authority" was a thinly veiled effort to equate LDF with carpetbaggers who had disrupted Atlanta's peace and tranquility.

The voice of the generation of black elites who had come to power in Atlanta after World War II was heard through the personage of John H. Calhoun, the former NAACP president, who was allowed to testify in favor of the compromise, though there was no evidence that he had children in the school system. ${ }^{153}$ The court also allowed extended family of children in the school system, who likewise were not plaintiffs, to testify. Ruby L. Edwards claimed authority to speak because she was a grandmother of children in the school system. Edwards's opinion that the settlement should be adopted was predicated

\footnotetext{
151 Id. at 44 .

152 Id. at 20.

${ }^{153}$ Id. at $70-71$.
} 
on her family's employment interests and her conviction that black teachers were as good as white ones: Edwards had two daughters teaching in the Atlanta schools, she proclaimed, and she was sure that "they are just as competent as white teachers." 154

A few of the African Americans who spoke in favor of the settlement were parents of children attending Atlanta's public schools. Doris Arnold was one such parent, as well as president of the PTA of L.J. Price High School. Her statement revealed her allegiance to that historically black institution as well as her view that anyone who opposed the settlement had fallen under the influence of outsiders. Arnold asked the court to adopt the plan supported by the local NAACP rather than listen to "national organizations" that were "trying to come to our city, trying to disrupt" local decision makers. ${ }^{155}$ In this way, Arnold's testimony tracked the rhetoric of the Community Relations Commission's February 27 resolution. ${ }^{156}$

There were some notable exceptions to the insider-versus-outsider mentality, however. Gladys Stroub was one of two mothers who made direct appeals to the court in favor of the settlement without reference to LDF's status as an outsider. ${ }^{157}$ Her appeal was based on her circumstances as a poor mother of nine children and resident of the Perry Homes housing project. ${ }^{158}$ Stroub supported the settlement because she did not want her children to be bused across town-out of her reach. "I wouldn't feel right," she explained. ${ }^{159}$

\section{Opportunities Lost and Found}

Despite the diversity of opinions on the issues addressed, the March 29 hearing was a failure on a number of fronts. First, considering the thousands of individuals whose rights were implicated by the proposed settlement of Calhoun, relatively few people seized the opportunity to express an opinion about the plan. And yet, such a low rate of participation was almost a foregone conclusion. Decades of elite control, together with an ineffective student movement and civil rights lawyers who had failed to engage their client base, had left most

\footnotetext{
${ }^{154} I d$. at 26 .

155 Id. at 21.

${ }^{156}$ See supra text accompanying note 152 (reproducing the Community Relations Commission's resolution, which praised local efforts at improving education for all stu-

${ }^{157}$ Record of Mar. 29, 1973, supra note 143, at 48-49.

158 Id. at 48 .

${ }^{159} \mathrm{Id}$.
} dents in Atlanta). 
black Atlantans, especially the working class and poor, ignorant of the mechanisms for exercising influence on public policy and disinclined to involve themselves in such matters. ${ }^{16}$

Nevertheless, the ACLU-affiliated attorney, Margie Hames, was able to turn out some of her clients. Armour plaintiffs like Ethel Mae Mathews and Mamie Dixon challenged the propriety of the settlement in an informed, thoughtful, and passionate manner. ${ }^{161}$

By contrast, judging from the paucity of Calhoun plaintiffs at the March 29 hearing, it appears that LDF's Moore had made little effort to involve class members in the process. Nor was any effort apparently made to explain to those plaintiffs who did appear that their comments should state a point of view on the propriety of the settlement-that this was their chance to influence the judges in whose hands their children's futures lay.

The hearing demonstrated in a striking manner the consequences of LDF's disengagement from the client community it represented. As Mary Sanford, a public housing tenant, explained at the hearing, she and other parents needed an organization that would represent parents of school-aged children so that they would know their rights and know how to advocate for equal education. ${ }^{162}$ As the attorneys of record for the plaintiffs for over fifteen years, LDF presumably should have been that organization.

\section{E. An Impartial Court Responds to the Opposition?}

The LDF attorneys were not alone to blame for the chaos in court on March 29. The hearing also demonstrated the court's indulgence of the settlement's backers. That so many supporters of the settlement plan at the hearing were not even plaintiffs raises serious questions about whether their testimony had been arranged by the settlement's negotiators. The court's failure to adhere to its stated rule of allowing only plaintiffs to speak revealed a lack of control over the proceeding - a situation that fundamentally undermined the plaintiffs' due process rights. Furthermore, the judges did not fulfill their duty to elicit and consider the plaintiffs' views regarding the proposed settlement. For instance, the judges did not ask the speakers questions that might have clarified the speakers' remedial preferences-a

\footnotetext{
${ }^{160}$ See Brown-Nagin, supra note 43, at ch. 2 (discussing biracial negotiation strategy for achieving civil rights); $i d$. at ch. 3 (discussing the failure of the student movement).

${ }^{161}$ See supra Part II.D.2 (recounting the Armour plaintiffs' testimony).

162 Record of Mar. 29, 1973, supra note 143, at 58-60.
} 
critical failure in light of the number of speakers who omitted any recommendation regarding approval of the settlement. ${ }^{163}$ Moreover, the judges scheduled the hearing for ten o'clock in the morning, ${ }^{164}$ a time when few working-class people could arrange to attend. As one speaker, Evelyn Parham, explained to the court:

I feel like a lot of black people work when you all meet and they can't get off to come, and maybe this is a lot of the problem of what's going on in [] the schools. They can't push as a white person can leave their job, they can't push for what they need in the school; so they sit back and have to go along with the decision that the people make across the boards and all. ${ }^{165}$

Parham's comments revealed the decision makers' failure to comprehend basic facts about the life circumstances of the working poor, as well as the powerlessness to influence the legal process that those most affected by the settlement felt.

The court reaffirmed its limited patience with those who attempted to thwart the settlement plan by rejecting efforts to challenge the settlement on constitutional grounds. Attorneys for LDF, the ACLU, and CORE had filed motions pointing out various ways in which the deal brokered by King and Spaulding was unlawful. ${ }^{166}$ One by one, the district court rejected them, and it did so without granting the attorneys a chance to argue their points in court. ${ }^{167}$ Howard Moore's decision to challenge the settlement solely through written objections proved a miscalculation, as the court rejected LDF's supplemental objections on the same day that they were filed and also spurned Moore's plea to be heard on the matter. ${ }^{\text {lis }}$ Over Moore's protests, the judges ruled that a full hearing on LDF's contention that the settlement was unconstitutional would be contingent on its rejection of that very plan. "If we reject the proposed settlement, there will be further hearings; if we do not, this will be the last hearing," Judge Smith retorted to Moore's suggestion that the court was denying the plaintiffs due process by refusing to allow him to argue his objec-

${ }^{163}$ See Record of Mar. 29, 1973, supra note 143 (showing a lack of follow-up questions by the judges after the speakers' testimony).

${ }^{164}$ Notice of Hearing, Mar. 12, 1973 at 1-3, Calhoun (No. 6298) (on file with NAACP Papers, part V, box 682).

${ }_{165}$ Record of Mar. 29, 1973, supra note 143, at 54-55.

${ }_{160} I d$. at $4-5$.

${ }^{167} \mathrm{ld}$. at $4-16$.

168 Id. at $14-16$. 
tions. ${ }^{169}$ The court's rationale for its decision was circular and implied its predisposition to approve the deal.

Such circularity and predisposition were also evident in the court's response to the efforts of CORE and the national NAACP to become involved in the case. ${ }^{170}$ The NAACP's motion to intervene was based on general counsel Nathaniel Jones's argument that neither the LDF attorneys nor Spaulding was adequately representing the interests of the class members. ${ }^{171}$ According to Jones's motion, Spaulding was attempting to gain approval for a settlement that was inconsistent with the law mandating meaningful pupil desegregation. ${ }^{172}$ "We have more parties and lawyers than we can handle now," Judge Smith explained in rejecting Jones's claims that the national NAACP had a special interest in the case $;^{179}$ he continued by saying, "there are about 75,000 plaintiffs in the case, and we cannot have separate lawyers for every one of them." ${ }^{\text {"74 }}$ The court went further, saying that no more hearings or discovery were needed because " $[\mathrm{w}] \mathrm{e}$ have fifteen years of evidence in the case." ${ }^{\text {} 75}$ The court's quips skirted Jones's point that the settlement had raised an entirely different issue than had ever been presented in the case before and thus demanded new evidence.

Judge Smith gave similarly pat answers to Charles Conley, CORE's attorney, who at a February press conference had denounced Lonnie King for "trading off quality education for a few big jobs for a few big Negroes." poor class members in northwest Atlanta's Archer school community would rather remain in their neighborhood schools than bear the brunt of busing, as required of them under the deal King had brokered, while schools such as Douglass, Harper, and Washington, located in "middle and upper income black communities," went unaffected. $^{177}$ "It appears quite clearly that the plan discriminates in favor of the more well-to-do sections," Conley argued at the March 8 hear-

169 Id. at 16.

177) See id. at 414 (denying the motions of CORE and the NAACP to intervene).

${ }_{171} I d$. at 5 .

172 Id.

173 Id. at 6 .

${ }^{174} I d$. at 12 .

175 Id. at 10 .

176 Jim Stewart, CORE Hits NAACP with Counter Bus Suit, ATLANTA CONST., Feb. 23, $1973, \S \mathrm{A}$

${ }^{177}$ Petition of the Congress of Racial Inequality, Inc. at 2, Calhoun (No. 6298) (on file with NARA, case file, part V, box 682). 
ing. ${ }^{178}$ On March 29 the court denied for a second time Conley's motion to enter the case. ${ }^{179}$ " $[\mathrm{O}]$ ne thing this case doesn't need is a few more lawyers," had been Judge Smith's reply to Conley on March $8,{ }^{180}$ and he maintained this stance three weeks later when Nathaniel Jones moved for the NAACP to intervene. ${ }^{181}$ This was the judge's position, notwithstanding the fact that Conley, like Hames, had tried mightily to impress upon the court that the settlement plan was particularly unfair, inadequate, and unconstitutional with respect to poor and working-class plaintiffs-the most educationally needy and vulnerable children. $^{182}$

Hames's objections to the settlement on behalf of the Armour plaintiffs--twenty-six impoverished parents with children in the school system who were said to represent 4000 other poor parents-were not as easily dismissed as the other challenges. ${ }^{183}$ In addition to claiming that the settlement was unconstitutional in its substance and prejudiced her clients' ability to attain metropolitan relief, Hames contended that the plan should be rejected because the process that produced it was tainted. ${ }^{184}$ Hames alleged that Lonnie King, a chief negotiator of the plan, had a conflict of interest because of his finan-

${ }^{178}$ Record of Mar. 8, 1973, supra note 118, at 22.

${ }^{179}$ Record of Mar. 29, 1973, supra note 143, at 45.

${ }^{180}$ Record of Mar. 8, 1973, supra note 118 , at 20.

181 Record of Mar. 29, 1973, supra note 143, at 11-12.

182 Id. at 4-16; see Supplemental Objections, supra note 117, at 1-4 (objecting to the plan because of the possibility that some schools would not receive equal attention in the compromise); Stolee Affidavit, supra note 113, at 1-15 (testifying that some schools would be completely omitted from the desegregation process); Motion of the NAACP to Intervene as Plaintiffs at 1-4, Calhoun (No. 6298) (on file with NAACP Papers, box 683) (stating the NAACP's intent to intervene on behalf of all black plaintiffs in the class); Record of Mar. 8, 1973, supra note 118, at 18-25 (containing CORE attorney Conley's motions to intervene); Petition for Intervention as a Party Plaintiff, Feb. 21, 1973 at 1-4, Calhoun (No. 6298) (on file with NAACP Papers, box 682) (containing CORE's motion to intervene on behalf of its clients); Stewart, supra note 176 (noting CORE's accusation that the NAACP was "trading off quality education for a few big jobs for a few big Negroes"”). Although the court rejected Conley's request to become formally involved in the case, the judges did give him the opportunity to file an amicus brief on behalf of CORE. See Record of Mar. 8, 1973m supra note 118, at 3 (transcribing Judge Smith's remark to Conley that "while we denied you intervention as a matter of right, . . . we would be glad to hear from you as a matter of amicus").

${ }^{183}$ See Record of Mar. 29, 1973, supra note 143, at 7 (noting Hames's objection to the Armour settlement); see also Supplemental Objections, supra note 117, at 1-4 (explaining that the Amour plaintiff class objected to the settlement because it was not comprehensive); Stolee Affidavit, supra note 113, at 1-15 (arguing against the plan because it would leave many schools still segregated).

${ }^{184}$ Record of Mar. 8, 1973, supra note 118 , at 15-18. 
cial relationship with William VanLandingham, vice president of the Citizens and Southern Bank (C\&S Bank), school board member, and the school board's chief negotiator in the settlement talks with King.

This allegation was based on documentary evidence-namely, a contract showing that Lonnie King, as general manager and project director of the Onyx Corporation, an educational consulting service, had received $\$ 198,857$ from VanLandingham's bank. ${ }^{185}$ The sum was paid in connection with a contract that King had been awarded to provide assistance to the Department of Health, Education, and Welfare (HEW), an agency for which he previously had worked, regarding local Head Start grantees. The transaction between King and C\&S Bank occurred in August 1972, around the same time that King began negotiations with VanLandingham, Frank Smith, John Letson, and Griffin Bell to settle Calhoun. ${ }^{186}$ Moreover, Benjamin Spaulding, the attorney whom King had hired to replace LDF in the school desegregation case, served as King's counsel for the negotiations with the bank and had been a signatory to the contract. Spaulding also had attained a personal loan from C\&S Bank during this period.

In light of this evidence, Hames argued that King, Spaulding, VanLandingham, and the C\&S Bank, among others, should be required to answer questions about their relationship and its impact on the settlement negotiations. Specifically, Hames sought to raise questions about King's and Spaulding's abilities to serve as adequate representatives of the plaintiffs considering their financial dealings with a defendant. ${ }^{188}$

The concern about a financial conflict of interest also pointed to a different kind of question: What had caused Lonnie King's sudden about-face regarding the propriety of pupil desegregation? In his position in HEW's Office of Civil Rights during the 1960s, King had helped to draw up desegregation plans for several cities, and as late as March of 1969 he had written of his support for "desegregated and quality education" in a letter to national NAACP chairman Roy Wilkins describing the "bold and ambitious" program of the branch's

${ }^{185}$ See Motion to Reconsider, supra note 79 (submitting evidence of the improper relationships among the negotiators).

${ }^{186}$ Id.

${ }^{187}$ See id. at 1-9 (asking for reconsideration of the settlement because of alleged collusion among some of the plaintiffs' attorneys).

${ }^{188}$ Record of Mar. 29, 1973, supra note 143 , at 7. 
"new leadership." ${ }^{189}$ Two years later, King's tune had changed radically: he had become leader of an effort to unseat LDF as counsel in Calhoun and settle the case on terms that unequivocally deemphasized pupil integration.

Years later, when King was asked to explain his actions, he stated that the settlement agreement sprang from his desire to promote black administrative control of the school system. ${ }^{190}$ King asserted that, whereas a white administration would resist court orders that furthered equality, black administrators would facilitate the implementation of court orders mandating educational equality. ${ }^{191}$ Yet, the settlement he negotiated changed the status quo in the school district so little that his explanation for trading pupil integration for black administrative control is hard to understand. After all, there were few, if any, real policy changes to implement under the settlement.

Nevertheless, as I have explained in another article, one of the troubling, unintended consequences of LDF's school desegregation campaign was job loss by African American administrators and educators. Many black school principals and teachers were subjected to retaliatory and discriminatory discharges and demotions during the transition to desegregated schools. ${ }^{192}$ There is no evidence, however, that this general trend held in Atlanta or that it motivated the settlement negotiations. Neither King nor any other black leader of the compromise effort suggested that the settlement was predicated on a desire to stem a pattern of discrimination against Atlanta's educators. Moreover, whereas the Fifth Circuit precedent that was the predicate for LDF's school plan mandated faculty desegregation throughout the school district, ${ }^{193}$ the settlement agreement guaranteed jobs for just a few African American administrators and did not protect the jobs of black teachers. ${ }^{194}$ Hence, the settlement agreement achieved much

\footnotetext{
${ }^{189}$ Letter from Lonnie C. King, Jr., President of the Atlanta Chapter of the NAACP, to Roy Wilkins, Chairman, National NAACP (Mar. 19, 1969) (on file with NAACP Papers, box C27, 1968-69 file).

${ }^{190}$ McGrath, supra note 50, at 329-31, 334, 337-38.

191 Id. at 337.

192 Brown-Nagin, supra note 17 , at 106.

103 See Singleton v. Jackson Mun. Separate Sch. Dist., 419 F.2d 1211, 1218 (5th Cir. 1969) (per curiam) (requiring for the 1969-1970 school year that the ratio of black to white staff members be substantially the same as that of black to white teachers); see also Singleton v. Jackson Mun. Separate Sch. Dist., 426 F.2d 1364, 1365 n.2 (5th Cir. 1970) (adopting the faculty-staff assignment ratio as the standard for a unitary system).

194 See supra text accompanying notes 67-69 (discussing the school board's pledge to increase the number of "key positions" available to blacks); see also supra text accompanying notes 111-12 (explaining the compromise settlement's creation of administra-
} 
less than the law required regarding faculty desegregation; at the same time, the agreement spurned meaningful pupil integration, again achieving much less than the law required. Under these circumstances, King's justification for the settlement's terms rings hollow.

Could greed have been the motive for the settlement? Did the $\$ 198,857$ loan represent a quid pro quo in which King and Spaulding agreed to involve the local NAACP in the litigation and formulate a settlement to the liking of VanLandingham and the school board in exchange for the fee? This is impossible to know without an admission from King, Spaulding, or VanLandingham. Yet, even if there had not been such a payoff, the very fact that King and Spaulding had entered into a financial relationship with the primary defendant in the school desegregation case (a case that they were now trying to settle as plaintiffs' representatives) represented a clear conflict of interest. Such a close relationship between putative adversaries certainly created the impression that King and Spaulding had not been suitable representatives for the plaintiffs. Since the deal between the two allegedly departed in such a fundamental way from constitutional norms, it left the impression of impropriety especially strong. ${ }^{195}$

This arrangement was particularly suspicious because Hames's objections were not limited to King's and Spaulding's financial entanglements with VanLandingham. There was evidence of other ethical improprieties that called into question King's fitness to serve as plaintiffs' representative. Hames brought to the court's attention an allegation, first made in a newspaper article, that King had duped at least two of the eight named plaintiffs whom he claimed to represent into granting him power of attorney. ${ }^{196}$ These two plaintiffs, whose names were withheld in the article, had informed a reporter that King and another local NAACP officer, Jondelle Johnson, had "lied" to them by telling them that "the NAACP needed a local attorney" because LDF was from outside Atlanta. ${ }^{197}$ These two plaintiffs were further told that

tive positions for African Americans and its ambiguity with respect to racial balance for teachers).

${ }^{1955}$ Under the canons of professional responsibility for lawyers, Spaulding was required to exercise independent professional judgment on behalf of his clients and to provide his clients with zealous representation. See MODEL CODE OF PROF'L RESPONSIBILITY EC 5-1 (1969) (requiring independent judgment by attorneys); $i d$. at EC 7-1 (requiring zealous representation of clients). Similarly, in his capacity as putative power of attorney for a handful of plaintiffs, King was required to act in these clients' best interests.

${ }_{197}^{196}$ Raffauf, supra note 79 , at 4 .

${ }^{197}$ Id. 
"[i]f they would sign the papers [granting powers of attorney], this all could be taken care of."198

If true, the plaintiffs' allegations were powerful. They suggested that King and Johnson had misled the plaintiffs about the status of the case. Contrary to King's and Johnson's alleged statements, the local NAACP had no official role in the case. Thus, the claim that the NAACP needed "a local attorney" was both untrue and a non sequitur. Also left unsaid was that the alleged sudden need for "local" counsel was the product of King's own ambitions and not of any shortcoming in LDF's representation identified by the court or any party. ${ }^{199}$ The suggestion that King had used false pretenses to obtain powers of attorney, which he then manipulated to depose LDF and install his own hand-picked attorney, was shocking. ${ }^{200}$

If proven, Hames's explosive allegations surely should have prevented approval of the settlement. In a meeting with Judge Henderson concerning her request that King, Spaulding, VanLandingham, and others submit to questions under oath about the nature of their relationships and their influence on the settlement proposal, Hames pointedly framed the issue of King's and Spaulding's fitness to represent the plaintiffs: "I represent people who feel like there has been a trade-off of rights of innercity [sic] black children for, whether you call it black jobs or whether you call it the personal gain or benefit of Lonnie King, [or] both." ${ }^{201}$

Neither the court nor Spaulding, who appeared on behalf of Lonnie King, expressed an interest in discussing the substance of Hames's assertions. Instead, King and Spaulding relied on technicalities to avoid answering Hames's allegations. Spaulding claimed that because he was the attorney of record for the plaintiffs, Hames had no legal standing to question his representation of the plaintiffs. ${ }^{202}$ Hames, in turn, stressed that her clients were members of the plaintiff

${ }^{198}$ Id

199 See id. (recounting the various ways Lonnie King profited by replacing LDF with Spaulding).

${ }^{200}$ See Supplemental Objections, supra note 117, at 3 (alleging that King and Spaulding were subject to conflicts of interest and objecting to their representation of the plaintiffs); Motion to Reconsider, supra note 79, at 1-9 (requesting reconsideration of an order denying the right to take discovery depositions to investigate King's and Spaulding's potential conflicts of interest arising from their connection with a bank loan from VanLandingham's bank to King's Onyx Corporation).

${ }^{201}$ Record of Mar. 26, 1973 at 13, Calhoun (No. 6298) (on file with NAACP Papers, part V, box 685).

202 Id. at 4. 
class and had objections to Spaulding's participation in the case, a fact that Hames (as their attorney) had a duty to raise. ${ }^{209}$

After a lengthy colloquy between Hames and Judge Henderson, the court embraced Spaulding's perspective. ${ }^{204}$ In doing so, the court ignored the fact that the plaintiff class was split into two opposing factions, one of which had never consented to Spaulding's representation and presumably retained the right to object both to Spaulding's participation in the case and to the substance of any settlement that Spaulding and King had negotiated. Disregarding Hames's concerns about conflicts of interest and collusion, Judge Henderson remarked that he was "weary" of hearing claims that King and Spaulding were improper representatives, given that Hames and LDF had not objected to their entry in the case in December 1972. ${ }^{205}$ "I am not going to permit this case to be used as a vehicle for everybody to vent their own personal feelings against everybody in the case, or their suspicions about everything," Judge Henderson stated. ${ }^{206}$ With this, the court ensured that there would be no truth seeking regarding Hames's extraordinary allegations, notwithstanding legal precedent dictating that courts thoroughly evaluate the circumstances surrounding contested settlements and claims of inadequate representation. ${ }^{207}$ Neither King nor Spaulding was ever asked to answer questions under oath about his financial dealings with VanLandingham or the circumstances surrounding the powers of attorney they had obtained. ${ }^{208}$

Nor would the court give any credit to objections to the settlement raised by class members at the March 29 hearing. Judges Smith and Henderson issued an opinion approving the settlement just a few days

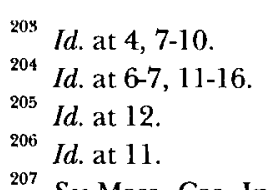

${ }^{207}$ See Mass. Cas. Ins. Co. v. Forman, 469 F.2d 259, 261 (5th Cir. 1972) (per curiam) (holding that under Florida law, a court must give parties a "full and fair opportunity to prove their version" of events where a dispute exists regarding the status of a settlement); Cia Anon Venezolana de Navegacion v. Harris, 374 F.2d 33, 35 (5th Cir. 1967) (stating that where the authority of an attorney to negotiate a settlement is in question, the agreement is binding unless the negotiations were not in good faith or there is sound evidence that the attorney was not authorized by the client to settle); of. Eisen v. Carlisle \& Jacquelin, 391 F.2d 555, 562 (2d Cir. 1968) (holding that representation by a named plaintiff is inadequate where the representative does not eliminate the possibility that some plaintiffs have interests antagonistic to other plaintiffs).

${ }^{208}$ Record of Mar. 26, 1973, supra note 201, at 2-17; Motion to Reconsider, supra note 79 , at 1-3; Supplemental Objections, supra note 117 , at 3-5. 
after the hearing. ${ }^{209}$ On April 4, 1973, the district court brought an end to Calhoun, which it termed "an ancient class action," ${ }^{210}$ concluding that the settlement negotiated by King and VanLandingham was "fair, adequate and reasonable." 211 The court was unmoved by the four organizations' claims that Spaulding's late entry into the case, under dubious circumstances, invalidated the settlement. Citing LDF's colossal strategic blunder-the failure at the December 1972 hearing to challenge Spaulding's entry into the case-the court refused to recognize what it characterized as Moore and Rindskopf's belated attempt to repudiate the settlement. ${ }^{212}$ LDF's "eleventh hour maneuvering" was "inconsequential and without legal effect," the court determined. ${ }^{213}$ The only reference to the plaintiffs who objected to the settlement was confined to a footnote, where the court remarked that the plaintiffs' objections were "minimal" considering the size of the class. ${ }^{214}$

Initially, it seemed that the Fifth Circuit might be inclined to agree with the contention that the settlement was improper both as a matter of equal protection and because of the procedurally inadequate manner in which the settlement had been put before the court. In an August 21, 1973, opinion, the Fifth Circuit found that Judges Smith and Henderson had given only perfunctory consideration to the objections to the settlement and had improperly approved the settlement over the objections of plaintiffs' attorneys. ${ }^{215}$ Whereas the district court judges had all but ignored the controversy surrounding King's and Spaulding's entries into the case and settlement negotiations, the appeals court concluded that "no plan can be approved as ... valid" where such "widespread and genuine controversy" exists. $^{216}$ Vacating the decision approving the settlement, the Fifth Circuit ordered the district court to allow the three groups of plaintiffs' attorneys to present evidence on the merits of the proposed settlement. $^{217}$

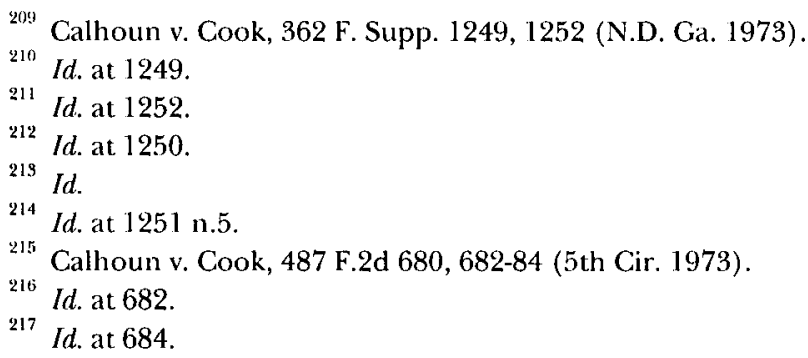


But after remand and another round of hearings in the district court, which resulted in yet another finding that the settlement was proper and the school system unitary, the Fifth Circuit seemed worn down. This, despite the fact that the district court had recognized in a May 1974 order that the school board had not even complied with the limited teacher and pupil desegregation goals contained in the agreement. $^{218}$ In an opinion issued on October 23, 1975, the court of appeals bowed out of the fight over equal educational opportunity in Atlanta. Even while acknowledging the lack of success in integrating classrooms (ninety-two of 148 schools remained over ninety percent black), ${ }^{219}$ the court gave its approval for the district court to scuttle the desegregation techniques identified in Swann. ${ }^{220}$ The court did so despite conceding that "substantial precedent" tention that a formerly de jure segregated school system could not be considered unitary if it had never utilized Swann-type desegregation techniques. Remarkably, the court of appeals decided that Atlanta's public schools were exempt from Swann's desegregation dictates because of the racial identity of King and his supporters. It explained:

[F]or today and in Atlanta, the unique features of this district distinguish [it from] every prior school case pronouncement. The district court found that the black citizens who occupy the majority of the posts on the school board, in two-thirds of the posts in the school administration and staff and in over $60 \%$ of the faculty, as well as the numerous nonappealing black plaintiffs who agreed to and support the present plan attest the district's lack of discrimination against black students as well as its freedom from the effects of past race-based practices... In Allanta, where white students now comprise a small minority and black citizens can control school policy, administration and staffing, they no longer are. ${ }^{222}$

In the appeals court's judgment, the common racial identity of the plaintiffs and black school administrators trumped all other considerations, apparently even constitutional ones. Having dispensed with Swann and other constitutional concerns, the court dismissed as

${ }^{218}$ See Calhoun v. Cook, No. 6298, at 9 (N.D. Ga. May 1, 1974) (on file with NAACP Papers, box 55B, folder 6) ("[I]n twelve instances, the goal level of desegregation, although approached, was not actually attained.").

${ }_{219}$ Calhoun v. Cook, 522 F.2d 717, 719 (5th Cir. 1975).

${ }^{220}$ See id. at 720 (affirming the district court's approval of the King-sponsored plan, calling it "free of racial discrimination"); see also Swann v. Charlotte-Mecklenburg Bd. of Educ., 402 U.S. 1, 28 (1971) (identifying busing and "remedial altering of attendance zones" as appropriate desegregation techniques).

${ }^{221}$ Calhoun, 522 F.2d at 719.

${ }^{222}$ Id. (emphasis added) (citations omitted). 
insignificant any objections to the settlement based on King's role in it and its negative impact on working-class and poor African American families. $^{223}$

The Fifth Circuit's ruling represented a triumph of narrow, racialist thinking. Even as members of the plaintiff class repudiated the actions of a fellow African American, Lonnie King, the court assumed that no legally cognizable discrimination could exist in the school system because its superintendent and other administrators were African American and not all African Americans had voiced concern about ongoing discrimination. Whether born of indifference, cynicism, bias, or mere weariness of the difficulties inherent in adjudicating a complex civil rights class action, the Fifth Circuit's resolution of the case reflected the assumption that a unity of interest flowed from racial sameness. In relying on such reasoning, the court ignored the fact that working-class and poor blacks had spent three years expressing their opposition to a settlement that had been brokered by local black leaders in the name of the barely operative Atlanta branch of the NAACP.

\section{LESSONS LEARNED}

This Article's account of Brown's implementation in Atlanta has independent value as a historical work. At the same time, the narrative presented here speaks to broader, normative questions in constitutional history and law. Most notably, this narrative holds implications for continuing debates about the meanings of Brown $v$. Board of Education and Swann v. Charlotte-Mecklenburg Board of Education and the efficacy of public interest lawyers' efforts to achieve social change through law. This Part suggests how this account bears on some of these questions.

\section{A. Brown in Atlanta: The Importance of Local Legal History}

The overarching significance of the Atlanta narrative is its demonstration that shared racial identity did not imply a monolithic value set

\footnotetext{
${ }^{223}$ See id. (emphasizing the voluntary nature of the participation in busing to dismiss the plaintiffs' concerns that "the movement involved is entirely by black students"); see also Calhoun v. Cook, No. 6298 (N.D. Ga. Aug. 29, 1973) (on file with NAACP Papers, part V, box 683) (holding that alleged collusion between King and the defendants was not pertinent and would not be considered further); Calhoun v. Cook, No. 6298 (N.D. Ga. May 1, 1974) (noting that the only objections to the plan were filed by the Armourv. Nix "Metro Group" and the intervenors associated with Deborah Birt).
} 
about questions of social policy during a crucial phase of civil rights lawyers' efforts to implement Brown. During the mid-1970s, when the Supreme Court had finally made significant pupil integration possible through its decision in Swann, African Americans no longer agreed on the proper remedy for inequality in education. More particularly, this Article has demonstrated the relevance of intraracial class conflict to some African Americans' views on school desegregation. Class-related tensions influenced some poor plaintiffs' perceptions concerning the value of law for achieving social change and the value of the two types of remedies for unequal education proposed by their legal representatives: pupil desegregation, on the one hand, and administrative desegregation, on the other. Class-related preferences also influenced those middle-class decision makers who favored a remedy that gave African Americans administrative control over the school system and who designed a desegregation plan under which the burden of busing fell disproportionately on the shoulders of the black poor, while middle-class black students remained largely unaffected. In demonstrating the relevance of class to dynamics in Atlanta, the local legal history told here reveals the limitations of scholarship that privileges race or racism and doctrinal responses to them above all other factors in analyzing LDF's efforts to effectuate social change through the courts. ${ }^{224}$ The points of view, actions, and multifaceted identities of African Americans in local communities matter as well.

By focusing on the lives and actions of local people, this Article has sought to reorient the literature on LDF's litigation effort from its focus on lawyers, judges, and white resistance to the clientcommunities who were the putative beneficiaries of Brown. In so doing, the history of the Atlanta desegregation cases corrects the tendency to conflate Brown's vaunted place in American constitutional history with the social meaning of Brown in African American communities. $^{225}$ Stated differently, because it infuses the legal history of Brown's implementation with the social history of the client-

${ }^{224}$ The latest such effort, which asked several distinguished constitutional scholars to rewrite the Brown opinion, is WHAT BROWN V. BOARD OF EDUCATION SHOULD HAVE SAID (Jack M. Balkin ed., 2001).

${ }^{225}$ Brown routinely is celebrated by constitutional scholars as among the most important Supreme Court cases without reference to the case's actual impact on its intended beneficiaries. For examples of such scholarship, see id. See also David J. Garrow, The Supreme Court's Pursuit of Equality and Liberty and the Burdens of History, in REDEFINING EQualiTy 205 (Neal Devins \& Davison M. Douglas eds., 1998) (describing Brown, rather than Marbury $\%$. Madison, 5 U.S. (1 Cranch) 137 (1803), as the formative Supreme Court case that demarcates our modern era). 
communities who were Brown's intended beneficiaries, the narrative told here counters the notion that all of Brown's beneficiaries necessarily experienced the new constitutional norm in a uniform and positive manner. At the same time, it discredits the idea that Brown's failure to improve educational opportunities for all African American students can be attributed only to white opposition to, or middle-class preference for, racially integrated schools. ${ }^{226}$ The Atlanta story demonstrates that a constellation of factors influenced the course and efficacy of school desegregation litigation, and that among these factors was class-tinged disagreement among African Americans.

Perhaps the most important consequence of this Article's analysis of the Atlanta litigation is to upset the conventional wisdom regarding African American communities' perspectives on Brown. This truism, accepted since the publication of Serving Two Masters and advanced in numerous other scholarly works, is the suggestion that the African American community-especially the working class-disagreed with and did not benefit from the doctrine established in Brown. Under this view, the notion that racially separate schools inherently are unequal is sentimental in theory and ineffective in practice: the prevailing sentiment is that Brown's preoccupation with racial balance was disconnected from the practical matters about which most blacksworking-class and poor parents, in particular-were concerned, such as the quality of school instruction, uneven allocation of resources, and inadequate parental influence over decision making. ${ }^{227}$ Even scholars who vehemently support the view that Brown requires pupil integration concede the "truth" of this position, proving its prevalence

${ }^{226}$ See Bell, supra note 1, at 472-83 (arguing that, in predominantly black school districts, the NAACP placed too much emphasis on desegregation rather than education).

227 See, e.g., Raymond WOLTERS, THE BURDEN OF BROWN: THIRTY YEARS OF SCHOOL DESEGREGATION 3-8, 273-89 (1984) (addressing the impact of the Brown decision on five school districts and its failure to eradicate racial discrimination in education); Bell, supra note 1, at 471 ("The espousal of educational improvement as the appropriate goal of school desegregation efforts is out of phase with the current state of the law."); Kevin Brown, African-American Immersion Schools: Paradoxes of Race and Public Education, in CrITICAL RACE THEORY 415, 415-26 (Richard Delgado \& Jean Stefancic eds., 2d ed. 2000) (discussing the lack of cultural influence in law and its importance in education); Kevin Brown, Revisiting the Supreme Court's Opinion in Brown v. Board of Education from a Multiculturalist Perspective, in BROWN V. BOARD OF EDUCATION: THE CHAllenge FOR TODAY'S SCHOOLS 44, 44 (Ellen Condliffe Lagemann \& Lamar P. Miller eds., 1996) (arguing that if "local school systems decide to engage in further efforts to bring racially and ethnically diverse students together, it must not be on the ideological basis of the Supreme Court's school desegregation opinions," and that the "very kind of thinking about the issues of cultural diversity that Brown I was based upon is [what] must be overcome in order for true multicultural education to occur"). 
tion concede the "truth" of this position, proving its prevalence and influence. ${ }^{228}$ Social science studies showing that African American students in many communities choose integrated schools when they are available routinely are overlooked by commentators. ${ }^{229}$

The Atlanta narrative demonstrates the inaccuracy of this perspective in historical context. Brown was supported by many African Americans, the number of which is difficult to ascertain because of the social and legal dynamics that discouraged clients' active involvement in civil rights lawyers' efforts to implement Brown. Moreover, the segment of the Atlanta community that supported Brown was largely working-class and poor; it was not middle-class blacks who pursued integration because of a putative inferiority complex or allegiance to LDF's white benefactors. Thus, the correlation propounded in the literature between remedial preferences and class background does not hold in Atlanta, one of the three cities that has been invoked as a prime example of the phenomenon of middle-class support for, and black working-class resistance to, Brown. ${ }^{230}$ By undermining the accuracy of Bell's thesis as applied to Atlanta, this narrative calls into question its overall legitimacy.

That said, the Atlanta narrative does not suggest an overly broad conclusion about African American communities' perspectives on school desegregation. To the contrary, an overarching theme in this Article is that it is arrogant and dangerous to make sweeping conclusions about African American dispositions toward Brown. Such broad conclusions only serve to reinscribe and reinforce racialist and racist assumptions about African American behavior and attitudes. Reductionist stereotypes of the type advanced in the legal literature are an inappropriate foundation for a putatively progressive theory of equality in education and public interest lawyering. Even if wellintentioned, constitutional analyses that are predicated on such uncomplicated correlations between status and remedial preferences are

${ }^{228}$ See, e.g., Drew S. Days III, Brown Blues: Rethinking the Integrative Ideal, in REDEFINING EQUALITY, supra note 225, at 139, 150 ("Concerns about the burdens blacks have had to carry in the desegregation process, the degree to which integration requires assimilation and rejection of black values and institutions, and the ... problems presented for . . . black school systems in education extremis are causing growing numbers of blacks to rethink Brown's integrative ideal.”).

${ }^{229}$ For studies showing African American preference for integrated schools, see Amy Stuart Wells \& Robert L. Crain, Stepping over THE Color Line: AfricanAMERICAN STUDENTS IN WHITE SUBURBAN SCHOOLS 180-218 (1997).

${ }^{230}$ See Bell, supra note 1, at 482-87 (addressing school desegregation issues in Boston, Detroit, and Atlanta). 
acts of intellectual and political hegemony, the upshot of which may be to undermine clients' remedial aspirations in the name of advancing them.

Rather than suggesting that African American communities held a uniform and easily discernable point of view on Brown, this narrative demonstrates that African Americans held many points of view about the proper approach to achieving educational equality over time. This Article has shown that these perspectives were related to individuals' experiences and identities as members of a racialized group and as persons of higher or lower socioeconomic status-but not inexorably so. A range of factors-including interpersonal relationships and impersonal forces-superimposed themselves on the variables of race and class, making individuals' social outlooks highly contingent at any particular point in time. Historical analysis of the proper sort, then, is not "usable" in legal debates in the manner that some legal scholars would prefer."

\section{B. Of the Contingency of Sociolegal Change: Local People's Impact on the "Hollow Hope"}

My finding that a vocal segment of Atlanta's working class and poor supported Brown's remedial vision during the 1970 s over the opposition of a group of elite decision makers holds significant implications for the ongoing debate about the proper nature of remedies to address educational inequality. These working-class clients embraced Brown's original conception of equality, but they did not draw a hard and fast distinction between Brown as a doctrinal rule mandating racial balance (or dignitary equality and cosmetic change) and Brown as a legal mechanism for addressing concerns about in-school quality (or substantive educational opportunity). Hence, my analysis suggests that those who embrace formalistic conceptions of legal remedies in educational discrimination cases do a disservice to clientcommunities. These clients demand creative approaches to their problems that do not begin or end with neat legalisms. Hence, overweening concern with conceptual schemes imposed by a particular mode of constitutional interpretation or argumentation is antithetical

${ }^{231}$ See Martin Flaherty, History "Lite" and Modern American Constitutionalism, 95 ColuM. L. REV. 523, 529 (1995) ("[A]ny theory opting for reductive simplicity, especially for the sake of either democratic process or individual liberty, is likely to forfeit its claim to historical credibility, at least to the extent it purports to rest on the nation's nascent constitutional experience."). 
to effective public interest lawyering. This lesson was lost on LDF lawyers who championed the desegregation of Atlanta's schools during the crucial post-Swann stage.

My analysis further suggests a tension between the Supreme Court's desire in Swann to mandate compliance with Brown and its demand in the same case that school systems root out the vestiges of de jure segregation sixteen years after the remedial decree in Brown originally was entered, a period during which white resistance was consistent. $^{232}$ To state the point more bluntly, given the Court's foot dragging, the Atlanta litigation's end in such spectacular defeat for LDF is less a wonder than the fact that there were not many more Atlanta-like debacles post-Swann. By the early 1970s, American society had been revolutionized by the changes in social and political relations produced by Brown, even if, and in some cases precisely because, school districts had not widely complied with the letter of the law established in the case itself.

To recap just a few of the explosive changes related to Brown or white resistance to it, the Voting Rights Act of $1965^{239}$ had been passed and African Americans had been elected mayor in a handful of cities, Cleveland, Newark, and Atlanta included. ${ }^{234}$ Lyndon Johnson's Great Society programs had enlarged the welfare state and thereby raised the public's consciousness of poverty, creating an expectation among poor people that they were entitled both to subsistence and to influence political decision making. ${ }^{295}$ And a radicalized student movement and the Black Power movement had emerged, both emphasizing the abject conditions of blacks living in poverty and questioning the legitimacy of legal and political systems that did not address their fates. $^{2.96}$

${ }^{232}$ See Swann v. Charlotte-Mecklenburg Bd. of Educ., 402 U.S. 1, 15 (1971) ("The objective ... remains to eliminate from the public schools all vestiges of state-imposed segregation.").

${ }^{283}$ Pub. L. No. 89-110, 79 Stat. 437 (codified as amended at 42 U.S.C. $\$ 1971$ (2000)). Of course, the Civil Rights Act of 1964, Pub. L. No. 88-352, 78 Stat. 241 (codified as amended in scattered sections of 42 U.S.C.), was important as well.

${ }^{234}$ See Manning Marable, RaCe, Reform, and Rebellion: The SECOND RECONSTRUCTION IN BLACK AMERICA, 1945-1990, at 77, 92-113 (2d ed. 1991) (describing African Americans' struggle for political equality in the 1960s).

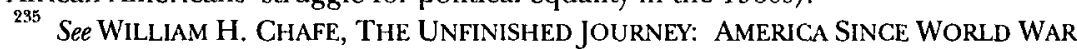
II 233-46 (1986) (addressing the accomplishments and failures of Johnson's Great Society programs).

See MARABle, supra note 234, at 93-99 (addressing the rise of "Black Power" between 1965 and 1970, the "dominant ideological concept" amongst black youths, and 
These circumstances, among others, set the stage for the internecine battles waged in Atlanta during the early 1970s, making Swann more of a lightning rod than the watershed constitutional event that the Court and many commentators have supposed. ${ }^{237}$ After the passage of so much time and the occurrence of so many significant changes in sociopolitical life, it was only logical that African Americans, in Atlanta and elsewhere, had developed differing opinions concerning the meaning of and the proper way to implement Brown.

In fact, this development-public discussion of divergent views by and among African Americans-was indicative of progress. After all, the civil rights movement liberated blacks from the constraints imposed by Jim Crow, not the least of which were stereotypes that forced a racebased sociopolitical cohesion born of disenfranchisement and disempowerment. Such cohesion was improbable after the chains of de jure segregation no longer bound African Americans together and discrimination began to affect different segments of African Americans in distinct ways.

By highlighting the vagaries of black social life post-Swann, the Atlanta narrative makes clear the interrelationship between legal change and social dynamics in African American communities. Typically, legal scholars have elided this interconnectivity in deference to legalized ways of viewing the world, epistemologies that make the perspectives and actions of legal actors paramount in analysis. This worldview wrongly discounts the agency of people affected by legal rules and misapprehends the ability of local, minority client-communities to influence and even undermine the implementation of antidiscrimination norms. ${ }^{238}$

the black working- and middle-class promotion of "the inclusion of all men in a common moral and political struggle").

${ }^{237}$ See DougLAS, supra note 48, at 212 ("The Supreme Court's Swann decision had an immediate impact across the South. [An] overwhelming majority of ... judges ordered the elimination of all majority-black schools ...."); GREENBERG, supra note 49, at 389 "We filed Swann motions in all our pending cases and, for the first time, thoroughgoing desegregation became widespread."); THOMAS W. HANCHETT, SORTING out The New SOUTh CitY: RaCe, Class, and Urban Development in Charlotte, 1875-1975, at 12, 251-53 (1998) (describing the Supreme Court's decision in Swann as a "landmark precedent for schools nationwide" because it "both summed up the results of decades of government-promoted segregation and also signaled the questions that were beginning to arise... concerning the desirability of a sorted-out city"). Douglas, the historian of Stuann and Charlotte, undoubtedly is correct that the case was successful in producing school desegregation in Charlotte, although my work shows that it clearly was not successful in Atlanta.

${ }^{238}$ By contrast, for examples of some of the most well-received recent historical works that have demonstrated the impact of lay citizens on developments in constitu- 
This lesson, lost on LDF, was understood well by the ACLU lawyer who followed the lead of local activists in filing the second Atlanta school desegregation case. Ultimately, the activists and their ACLU lawyer did not achieve their legal goals. This fact only reinforces the point made here, however, that law and social dynamics affect one another in complex ways. Hence, the ability to anticipate and respond to sociopolitical contingencies is a critically important factor affecting the success of social reform campaigns through law. Indeed, this skill is just as important as the ability to define the goals of social reform litigation and to develop strategies for reaching these goals, which logically are necessary skills for the "social engineer."

By recognizing the possibilities created when the local people affected by landmark legal victories exercise social agency, this narrative is saved from its most pessimistic reading. I do not mean simply to affirm that any belief in courts' ability to bring about significant social change is no more than a "hollow hope." ${ }^{240}$ The proper question is not whether courts alone can produce significant social change, ${ }^{241}$ but rather, how lawyers and advocates can create the sociopolitical conditions that give rise to social movements whose momentum the Supreme Court cannot stop when movement lawyers bring test cases before it. This Article has shed light on this inquiry by demonstrating that lawyers' disengagement from the client-community, especially one torn by internal tensions, will only exacerbate, rather than ame-

tional law post-Brown, see FaIrclough, supra note 27; CHARLES M. PAYNe, I've Got

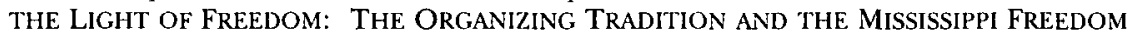
STRUGGLE 392 (1995).

${ }^{239}$ See GenNa RAE MCNEIL, GROUNDWORK: Charles Hamilton HOUSTON AND THE STRUGGLE FOR CIVIL RIGHTS 84-85, 133, 216-17 (1983) ("A social engineer was a highly skilled, perceptive, sensitive lawyer who understood the Constitution ... and knew how to explore its uses in the solving of 'problems of . . local communities' and in "bettering conditions of the underprivileged citizens." (second omission in original) (quoting Charles Houston)).

${ }^{240}$ See ROSENBERG, supra note 19 , at 338 (arguing that "U.S. courts can almost never be effective producers of significant social reform").

${ }^{241}$ Rosenberg admitted the futility of the "Dynamic Court" view in his study by suggesting an alternative "Constrained Court" view that admitted of the possibility that courts might contribute to social change under certain political, social, and economic circumstances. See id. at 5-6 (comparing and contrasting the "Constrained Court" and "Dynamic Court" views). In other words, ultimately he understood that the appropriate inquiry is not whether courts can produce significant social change, but under what conditions. The latter formulation is fit for the historian, and it is this more nuanced question that this Article addresses. 
liorate, the status-quo-preserving tendencies of law, undermining the possibility that courts will further efforts to achieve social change. ${ }^{24}$

\section{The Challenge of Difference amid Sameness}

Still, it is true that while other constitutional scholars and historians who have written about Brown v. Board of Education have tended to focus on the case as an example of law's positive impact on social life, this analysis has demonstrated the inadequacy of some of the concepts used to interpret the Fourteenth Amendment. Here, law's limitations have been described in terms of legal norms that enforce false notions of community. The Atlanta narrative is a cautionary tale regarding the substantive limits of the constitutional norms that judges and advocates rely on to resolve equal protection claims.

The stunningly unsatisfactory end to the Atlanta school desegregation campaigns suggests that the "sameness" concept relied on to settle disputes in equal protection jurisprudence-the convention that "likes" should be treated "alike" or that individuals classified as belonging to a common racial group have no differences salient to lawcan lead to faulty outcomes in the most difficult cases. It can frustrate the just resolution of race discrimination class actions when significant disagreement exists within a group whose constitutionally "suspect" status is based on racial identity. In Atlanta, not only the courts but also plaintiffs' own counsel largely ignored the intraracial conflict that developed in the case after Swann. The result of the legal actors' attitudes was to deny members of the class who objected to the Calhoun settlement any meaningful opportunity to have their concerns addressed. By disagreeing with other African Americans, the objectors upset the convention requiring minority groups to act as if all group members embrace a monolithic point of view. This interpretative norm-which is a constituent element of constitutional law-devalues, even punishes, expressions of dissent.

Of course, legal fictions are necessary; it is unreasonable to expect law to capture humankind's true complexity or to respond to the whims of every individual plaintiff. Thus, my quarrel is not with the sameness norm per se, but with legal actors' failure to appreciate that sameness is, after all, a socially constructed norm. It is a fine tool for

${ }^{242}$ For discussions of law's status-quo-preserving character, see GIRARDEAU A. SpanN, Race Against the Court: The Supreme Court and Minorities in Contemporary AMerica 3 (1993); Reva Siegel, Why Equal Protection No Longer Protects: The Evolving Forms of Status-Enforcing State Action, 49 STAN. L. REV. 1111 (1997). 
understanding the requirements of the Equal Protection Clause, but only where real intraracial differences, most particularly factors relevant to fashioning remedies, do not exist. Where, as in the Atlanta cases, intraracial differences are apparent, they must be confronted and addressed by plaintiffs' counsel and the courts.

The social and historical reality of difference amid sameness uncovered in this historical account both calls public interest lawyers to arms and stands to correct the notion within some scholarly circles that difference among individuals that experience group-based harm is of necessity a liability to efforts to achieve change through law. ${ }^{243}$ Admittedly, difference among "likes" makes for complexity because of the simplistic equation of status with rights in equal protection jurisprudence. If that complexity ultimately yields a remedial outcome more satisfactory to client-communities, however, then grappling with difference is, in the final analysis, a social good.

\section{CONCLUSION}

This Article has asserted the relevance of intraracial class dynamics as a factor constraining civil rights lawyers' efforts to implement the landmark social norm decreed in Brown v. Board of Education-the paradigmatic social reform class action. While this Article has endeavored to reintroduce class as an analytical factor in the legal literature that considers Brown, in particular, and social reform litigation, generally, I do not mean to replace one narrow mode of thinking (about race) with another (about class). Nor does the Atlanta story lend itself to such a distortion of my claim regarding the relevance of class. The effort here is an attempt to understand the interplay of class and race, and not to assert the analytical prominence of one variable over the other.

The overall lesson that the Atlanta narrative teaches is much broader than such a hierarchy of oppressions suggests. This story

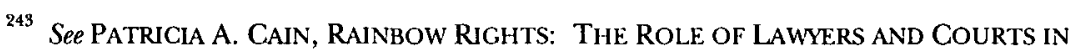
THE LESBIAN AND GAY CIVIL RIGHTS MOVEMENT 12-13 (2000) (characterizing the sameness argument for gay rights as easier to articulate politically, morally, and legally than the difference argument); see also Christine H. Rossell, The Convergence of Black and White Altitudes on School Desegregation Issues, in REDEFINING EQUALITY, supra note 225, at 120, 120-23 (utilizing data to show that, like many whites, many blacks do not view mandatory reassignment and busing as being in their self-interest and that this convergence of opinion makes the "public policy arena enormously complex," even while arguing that only the outnumbered "civil rights establishment" favors mandatory reassignment). 
demonstrates that class is but one of many factors that may influence plaintiffs' perceptions of the propriety of remedies for unequal education or for any of the other discriminations that groups may experience based on status. Hence, the goal for lawyers who represent groups that experience status-based infractions of their rights should be to bring as many of these influences as possible to bear on the task of fashioning remedies without destroying the solidarity among group members derived from a status-based harm. In other words, rather than assuming that the class-action approach to social change requires plaintiff uniformity around a particular goal or strategy, public interest lawyers should focus on ways in which the law can accommodate the multidimensionality of plaintiffs brought together as a class due to the continuing reality of status-based discrimination. In this way, law can expand to accommodate the real experiences of litigants rather than confine them to legal categories, such as the "suspect class" fiction, that are predicated on an imagined and rigidly categorized human condition. 